Key Words:

DWPF

Qualification

Retention:

Permanent

\title{
DEMONSTRATION OF THE DWPF FLOWSHEET IN THE SRNL SHIELDED CELLS WITH TANK 40 AND H CANYON NEPTUNIUM
}

\author{
J. M. Pareizs
}

B. R. Pickenheim

C. J. Bannochie

M. E. Stone

April 2009

Savannah River National Laboratory

Savannah River Nuclear Solutions

Aiken, SC 29808

Prepared for the U.S. Department of Energy Under

Contract Number DE-AC09-08SR22470

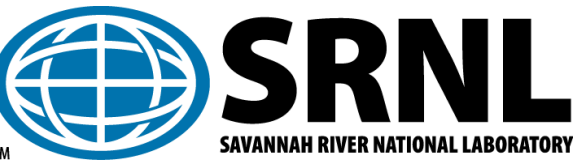




\section{DISCLAIMER}

This work was prepared under an agreement with and funded by the U.S. Government. Neither the U. S. Government or its employees, nor any of its contractors, subcontractors or their employees, makes any express or implied:

1. warranty or assumes any legal liability for the accuracy, completeness, or for the use or results of such use of any information, product, or process disclosed; or

2. representation that such use or results of such use would not infringe privately owned rights; or

3. endorsement or recommendation of any specifically identified commercial product, process, or service.

Any views and opinions of authors expressed in this work do not necessarily state or reflect those of the United States Government, or its contractors, or subcontractors.

Printed in the United States of America

Prepared for

U.S. Department of Energy 
Key Words:

DWPF

Qualification

Retention:

Permanent

\title{
DEMONSTRATION OF THE DWPF FLOWSHEET IN THE SRNL SHIELDED CELLS WITH TANK 40 AND H CANYON NEPTUNIUM
}

\author{
J. M. Pareizs
}

B. R. Pickenheim

C. J. Bannochie

M. E. Stone

April 2009

Savannah River National Laboratory Savannah River Nuclear Solutions

Aiken, SC 29808

Prepared for the U.S. Department of Energy Under

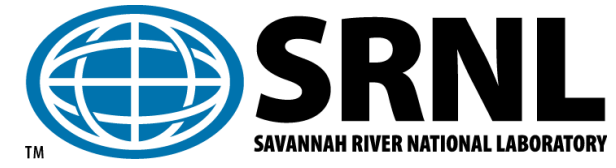




\section{REVIEWS AND APPROVALS}

\section{AUTHORS:}

J. M. Pareizs, Process Technology Programs

Date

B. R. Pickenheim, Process Technology Programs

Date

C. J. Bannochie, Process Technology Programs

Date

M. E. Stone, Process Technology Programs

Date

\section{TECHNICAL REVIEWERS:}

D. P. Lambert, Process Technology Programs

Date

\section{APPROVERS:}

C. C. Herman, Manager, Process Technology Programs

Date

S. L. Marra, Manager, E\&CPT Research Programs

Date

J. E. Occhipinti, Manager, Waste Solidification Engineering

Date 


\section{TABLE OF CONTENTS}

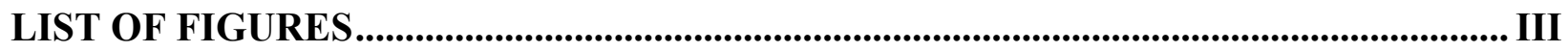

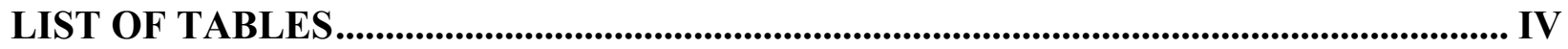

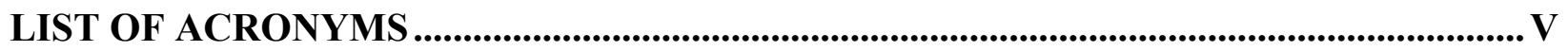

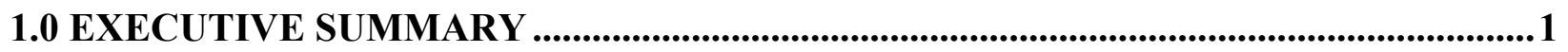

2.0 INTRODUCTION AND BACKGROUND ...........................................................2

3.0 APPROACH ........................................................................................................................3

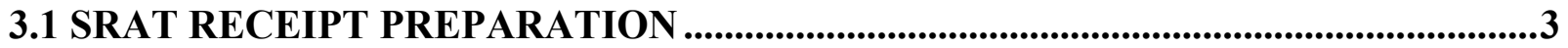

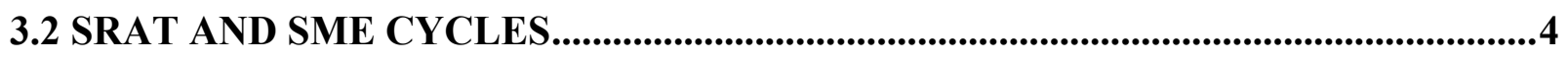

3.3 RHEOLOGY MEASUREMENTS ............................................................................6

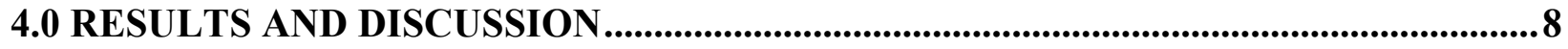

4.1 SRAT RECEIPT PREPARATION

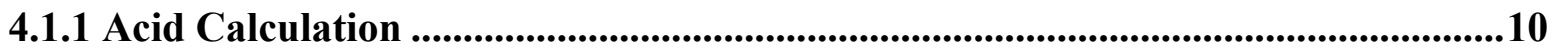

4.2 SRAT CYCLE ..............................................................................................................12

4.2.1 Nitrite Destruction and Mercury Removal .............................................................13

4.3 SME CYCLE .................................................................................................................15

4.4 SRAT AND SME ANTIFOAM ADDITIONS AND FOAMING ...............................15

4.5 ANION DESTRUCTION AND CONVERSION ....................................................17

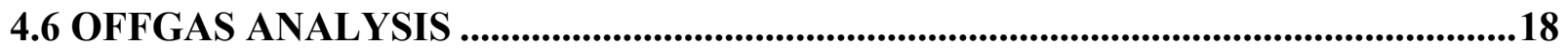

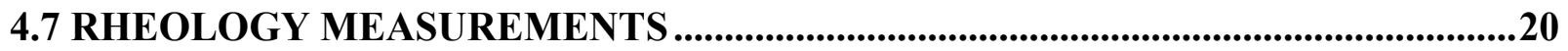

5.0 CONCLUSIONS ...................................................................................................................23

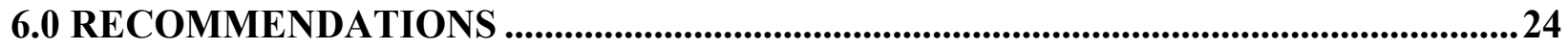

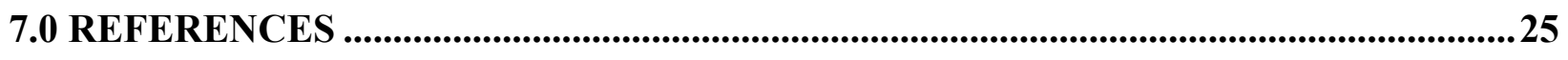

8.0 ACKNOWLEDGEMENTS .................................................................................................227

APPENDIX A. EXCERPT FROM TANK FARM PLANNING SPREADSHEET

SB456_010809B.XLS ...........................................................................................................28

APPENDIX B. DECANT AND ADDITION CALCULATIONS.........................................29

APPENDIX C. RESULTS OF SRAT CYCLE PERIODIC SAMPLES .............................32

\section{LIST OF FIGURES}

Figure 1. Schematic of SRAT Equipment Set-Up ...........................................................5

Figure 2. Photograph of SRAT/SME Apparatus in SRNL Shielded Cells ...........................5

Figure 3. Formate, Nitrate, and pH as a function of SC-8 SRAT Cycle Boiling Time ........13

Figure 4. Mercury Content of Total Solids as a Function of SC-8 SRAT Cycle Boiling

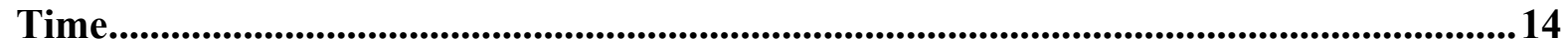

Figure 5. SC-8 SRAT Cycle Offgas Data (DWPF Scale) .......................................................19

Figure 6. SC-8 SME Cycle Offgas Data (DWPF Scale) ..........................................................19

Figure 7. Graphical presentation of SME Product Yield Stress Results...............................21 


\section{LIST OF TABLES}

Table 1. Summary of CPC Processing. 4

Table 2. MV I and MV II Rotor Specifications and Flow Curve Program ........................... 7

Table 3. Characterization Results of the SRAT Receipt Sample ...............................................8

Table 4. Comparison of Selected Tank Farm Projections to SC-8 SRAT Receipt.................9

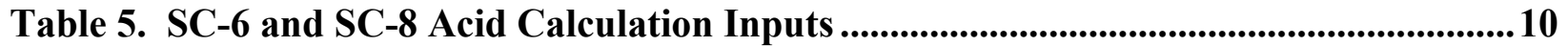

Table 6. SC-6 and SC-8 Acid Calculation Results.....................................................................11

Table 7. Characterization Results of the SC-8 SRAT Product ...............................................12

Table 8. Anions, Mercury, and pH of the SC-8 Periodic Samples .......................................12

Table 9. Characterization Results of the SC-8 SME Product ...............................................15

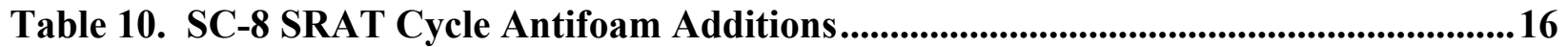

Table 11. SC-8 SME Cycle Antifoam Additions .............................................................16

Table 12. SC-8 Assumed and Measured Anion Destruction and Conversion with

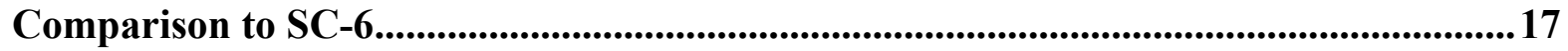

Table 13. Maximum Observed Hydrogen, Carbon Dioxide, and Nitrous Oxide Volume Percent and DWPF Scale Generation Rates during SC-8 CPC Processing.................... 18

Table 14. Rheology Measurements of SC-8 SRAT Receipt, SRAT Product, and SME

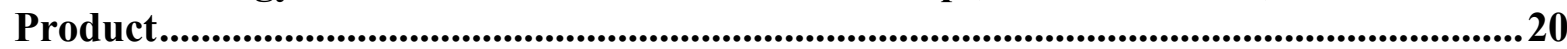

Table 15. Rheology of SC-8 SME Product at Various Weight Percent Total Solids ...........20 Table 16. Comparison Between SC-6 and SC-8 SRAT Receipt, SRAT Product, and

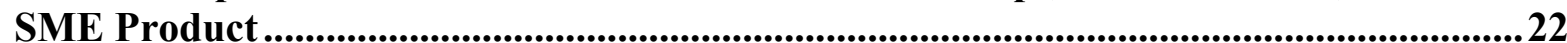




\section{LIST OF ACRONYMS}

ACTL

$\mathrm{AD}$

$\mathrm{CPC}$

DWPF

FAVC

GC

GC/MS

$\mathrm{IC}$

ICP-AES

IS

LWO

MWWT

NIST

QA

REDOX

RSD

SB4

SB5

SME

SMECT

SRAT

SRNL

SRS

SS

TIC

TOC

TS

TTQAP

TTR

WAPS
Aiken County Technologies Laboratory

Analytical Development

Chemical Process Cell

Defense Waste Processing Facility

Formic Acid Vent Condenser

Gas Chromatograph

Gas Chromatograph - Mass Spectrometer

Ion Chromatography

Inductively Coupled Plasma - Atomic Emission Spectroscopy

Insoluble Solids

Liquid Waste Organization/Operations

Mercury Water Wash Tank

National Institute of Standards and Testing

Quality Assurance

REDuction / OXidation potential

Relative Standard Deviation

Sludge Batch 4

Sludge Batch 5

Slurry Mix Evaporator

Slurry Mix Evaporator Condensate Tank

Sludge Receipt and Adjustment Tank

Savannah River National Laboratory

Savannah River Site

Soluble Solids

Total Inorganic Carbon

Total Organic Carbon

Total Solids

Task Technical and Quality Assurance Plan

Technical Task Request

Waste Acceptance Product Specification 


\subsection{EXECUTIVE SUMMARY}

The Defense Waste Processing Facility (DWPF) is currently processing Sludge Batch 5 (SB5) from Tank 40. SB5 contains the contents of Tank 51 from November 2008, qualified by the Savannah River National Laboratory (SRNL) and the heel in Tank 40 remaining from Sludge Batch 4. Current Liquid Waste Operations (LWO) plans are to 1) decant supernatant from Tank 40 to remove excess liquid caused by a leaking slurry pump and 2) receive a Np stream from $\mathrm{H}$ Canyon The $\mathrm{Np}$ stream contains significant nitrate requiring addition of nitrite to Tank 40 to maintain a high nitrite to nitrate ratio for corrosion control.

SRNL has been requested to qualify the proposed changes; determine the impact on DWPF processability in terms of hydrogen generation, rheology, etc.; evaluate antifoam addition strategy; and evaluate mercury stripping. Therefore, SRNL received a 3 L sample of Tank 40 following the transfer of Tank 51 to Tank 40 (Tank Farm Sample HTF-40-08-157) to be used in testing and to perform the required Waste Acceptance Product Specifications radionuclide analyses. Based on Tank Farm projections, SRNL decanted a portion of the sample, added sodium nitrite, and added a $\mathrm{Np}$ solution from $\mathrm{H}$ Canyon representative of the $\mathrm{Np}$ stream to be dispositioned to Tank 40 (neutralized to $0.6 \mathrm{M}$ excess hydroxide). The resulting material was used in a DWPF Chemical Process Cell (CPC) demonstration - a Sludge Receipt and Adjustment Tank (SRAT) cycle and a Slurry Mix Evaporator (SME) cycle. Based on these simulations:

- The DWPF can process Tank 40 following the targeted decant and addition of sodium nitrite and a Np-bearing stream from H Canyon. The SRNL simulations showed that:

- The DWPF hydrogen generation rate limits in the SRAT and SME cycles were not exceeded. The observed DWPF scale peak hydrogen generation rates were $0.24 \mathrm{lb} / \mathrm{h}$ in the SRAT cycle and $0.15 \mathrm{lb} / \mathrm{h}$ during the SME cycle.

- Nitrite was destroyed to below DWPF limits within twelve hours of boiling in the SRAT cycle.

- Mercury was removed to below DWPF limits within 28 hours of boiling in the SRAT cycle at a boilup rate of $2,500 \mathrm{lb} / \mathrm{h}$.

- The SRAT (and SME during canister decon dewatering) was prone to foaming as boiling progressed.

- Although rheological properties of SRAT and SME products exceeded DWPF design bases, SRNL had no difficulties in mixing or heating these materials.

- Based on these simulations, SRNL recommends:

- $\quad$ SRAT product solids concentration target of no greater than $20 \mathrm{wt} \%$ total solids

- $\quad$ SRAT boiling time (dewater plus reflux) of 28 hours at 2,500 lb/hr steam $(70,000 \mathrm{lb}$ of steam total) to ensure $\mathrm{Hg}$ reduction

- SME product concentration of $45 \mathrm{wt} \%$ total solids

- The following antifoam addition strategy:

1. $200 \mathrm{ppm}$ prior to SRAT cycle heatup

2. $100 \mathrm{ppm}$ after addition of nitric acid is complete

3. $500 \mathrm{ppm}$ after addition of formic acid is complete

4. 300 ppm every 6 hours of SRAT boiling

5. 300 ppm every 6 hours during canister decon boiling and 100 ppm each 8 hours during the rest of the SME cycle 


\subsection{INTRODUCTION AND BACKGROUND}

The Defense Waste Processing Facility (DWPF) is currently processing Sludge Batch 5 (SB5) from Tank 40. SB5 contains the contents of Tank 51 from November 2008, qualified by the Savannah River National Laboratory (SRNL) ${ }^{1}$ and the heel in Tank 40 remaining from Sludge Batch 4. Current Liquid Waste Operations (LWO) plans are to 1) decant supernatant from Tank 40 to remove excess liquid caused by a leaking slurry pump and 2) receive a $\mathrm{Np}$ stream from $\mathrm{H}$ Canyon It should be noted that the $\mathrm{Np}$ stream contains significant nitrate requiring addition of nitrite to Tank 40 to maintain a high nitrite to nitrate ratio for corrosion control.

SRNL has been requested to qualify the proposed changes; determine the impact on DWPF processability in terms of hydrogen generation, rheology, etc.; evaluate antifoam addition strategy; and evaluate mercury stripping. Therefore, SRNL received a 3 L sample of Tank 40 following the transfer of Tank 51 to Tank 40 (Tank Farm Sample HTF-40-08-157 to be used in testing and to perform the required Waste Acceptance Product Specifications radionuclide analyses). Based on Tank Farm projections, SRNL decanted a portion * of the sample, added sodium nitrite, and added a $\mathrm{Np}$ solution from $\mathrm{H}$ Canyon representative of the $\mathrm{Np}$ to be dispositioned to Tank 40 (neutralized to $0.6 \mathrm{M}$ excess hydroxide). The resulting material was used in a DWPF Chemical Process Cell (CPC) demonstration - a Sludge Receipt and Adjustment Tank (SRAT) cycle and a Slurry Mix Evaporator (SME) cycle. Preliminary data from the demonstration has been reported previously. ${ }^{2,3}$ This report includes discussion of these results and additional results, including comparisons to Tank Farm projections and the SB5 demonstration.

This work was requested by a Technical Task Request (TTR) ${ }^{4}$ and was guided by a Task Technical and Quality Assurance Plan (TTQAP) ${ }^{5}$ and Analytical Study Plan (ASP) ${ }^{6}$.

\footnotetext{
* The remaining Tank 40 material will be used for Waste Acceptance Product Specification (WAPS) characterization.
} 
SRNS-STI-2009-00233, REVISION 0

\subsection{APPROACH}

\subsection{SRAT RECEIPT PREPARATION}

The SRAT receipt sample was prepared using a portion of the 3 L SB5 - Tank 40 WAPS sample received by SRNL in November 2008 (Tank Farm Sample ID HTF-40-08-157). Due to water inleakage from the tank slurry pumps and a planned addition of $\mathrm{Np}$ from $\mathrm{H}$ Canyon, the Tank 40 sample was modified to match these changes. The as-received Tank 40 sample was characterized, ${ }^{7}$ and these results were used as the starting point for modification of the sample.

Per Tank Farm plans,

- A $100 \mathrm{kgal}$ decant from Tank 40 will be performed because of water in-leakage from slurry pumps that has diluted SB5 such that caustic boiling is required in DWPF to maintain a reasonable solids level, prior to sodium nitrite and $\mathrm{Np}$ stream additions.

- Sodium nitrite will be added after the decant to maintain the required nitrite to nitrate ratio for corrosion control upon $\mathrm{Np}$ addition. Note that the $\mathrm{Np}$ stream will add significant amounts of nitrate to Tank 40.

- Approximately $11 \mathrm{kgal}$ of a Np stream will be received into Tank 40 from the $\mathrm{H}$ Canyon Material Disposition Program.

An excerpt from Tank Farm Spreadsheet SB456_010809B, the basis for SRNL modifications to the Tank 40 sample, is included in Appendix A. The spreadsheet includes projected Tank 40 compositions before and after decant and additions; sodium nitrite addition quantity; and Npbearing $\mathrm{H}$ Canyon stream quantity and bulk composition (major sodium, nitrite, nitrate, and hydroxide).

An excerpt from Tank Farm Spreadsheet SB456_010809B, the basis for SRNL modifications to the Tank 40 sample, is included in Appendix A. The spreadsheet includes projected Tank 40 compositions before and after decant and additions; sodium nitrite addition quantity; and $\mathrm{Np}$ stream quantity and bulk composition (major sodium, nitrite, nitrate, and hydroxide).

SRNL repeated the planned operations with the exception of simulation of pump bearing water in-leakage. Water in-leakage was not simulated to ensure SRNL had a sample that bounded Tank Farm projections with respect to weight percent total and insoluble solids and nitrite, major inputs to the DWPF acid demand.

To estimate the adjustments that would be required for the SRNL Tank 40 sample,

- Decant amount was calculated using a volumetric ratio to the Tank Farm decant.

- Sodium nitrite amount (as a 40wt\% solution) was calculated using a volumetric ratio.

- The Np-bearing H Canyon stream volume was calculated using a volumetric ratio.

- The mass of $\mathrm{Np}$ added was calculated by multiplying the $\mathrm{H}$ Canyon discharge mass by the SRNL volume to Tank Farm volume ratio. An Np-bearing H Canyon sample from July 2008, which was representative of the planned $\mathrm{Np}$ transfer, was used as the source of $\mathrm{Np}$. Reagent chemicals (sodium hydroxide, nitric acid) and water were added to the sample to match the required neutralization and nitrate content of the $\mathrm{Np}$ stream for disposal. 
Since the Tank 40 WAPS sample had already been characterized, the resulting Np-adjusted material required minimal characterization. Weight \% solids, density, anions, and titration for base equivalents were characterized, while mercury and manganese content, required for the DWPF acid calculation, were calculated from the analysis of the as-received sample ${ }^{7}$ by mass balance with the assumption that mercury and manganese are insoluble (i.e., the decant did not remove significant mercury and manganese).

SRNL's calculations are shown in Appendix B.

\subsection{SRAT AND SME CYCLES}

DWPF simulations (SRAT and SME cycles) using the SB5 - Tank 40 WAPS sample with Np were conducted following procedures in the SRNL L29 procedure manual. ${ }^{8}$ A summary of each cycle is presented in Table 1.

Table 1. Summary of CPC Processing

\begin{tabular}{|c|c|}
\hline SRAT Cycle & SME Cycle \\
\hline $\begin{array}{l}\text { - Heating of SRAT Receipt to } \\
93{ }^{\circ} \mathrm{C} \\
\text { - } \\
\text { Addition of nitric and formic } \\
\text { acids per acid calculation } \\
\text { - } \\
\text { - } \\
\text { Conceating to boiling } \\
\text { to a target wt } \% \text { total solids } \\
\text { - Reflux to obtain a total time at } \\
\text { boiling of } 44 \text { hours }\end{array}$ & $\begin{array}{l}\text { - Addition and removal of water } \\
\text { to simulate addition and } \\
\text { removal of water from the } \\
\text { decontamination of } 5 \mathrm{DWPF} \\
\text { canisters } \\
\text { - Addition of frit and dilute } \\
\text { formic acid in two batches to } \\
\text { target } 34 \% \text { waste loading } \\
\text { - Concentration (water removal) } \\
\text { to target } 45-50 \mathrm{wt} \% \text { total } \\
\text { solids. }\end{array}$ \\
\hline
\end{tabular}

The CPC processing, designated as SC-8, was performed using a vessel designed to process one liter of sludge. For the in-cell run, the SRAT rig was assembled and tested in the SRNL Shielded Cells Mockup area and placed into the Shielded Cells fully assembled. A detailed description of the SRAT rig, and testing performed with the rig can be found in References 9 and 10. The intent of the equipment is to functionally replicate the DWPF processing vessels. The glass kettle is used to replicate both the SRAT and the SME cycles, and it is connected to the SRAT Condenser and the Mercury Water Wash Tank (MWWT). Because the DWPF Formic Acid Vent Condenser (FAVC) does not directly impact SRAT and SME chemistry, it is not included in SRNL Shielded Cells CPC processing. Instead, a simple "cold finger" condenser is used to cool offgas to approximately $20^{\circ} \mathrm{C}$ below ambient to remove excess water before the gas reaches the Gas Chromatograph (GC) for characterization. The Slurry Mix Evaporator Condensate Tank (SMECT) is represented by a sampling bottle that is used to remove condensate through the MWWT. For the purposes of this paper, the condensers and wash tank are referred to as the offgas components. A sketch of the experimental setup is given in Figure 1, and a photograph of the equipment in the Shielded Cells is shown in Figure 2. 


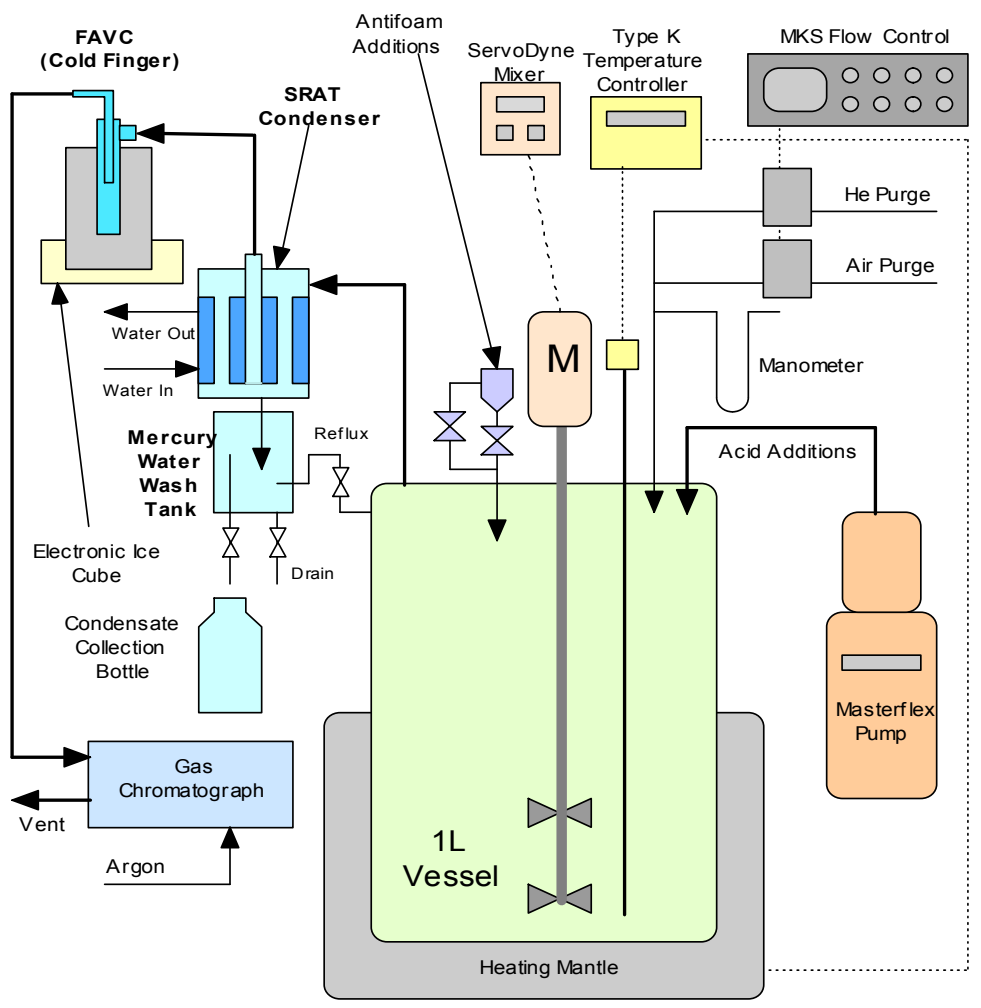

Figure 1. Schematic of SRAT Equipment Set-Up

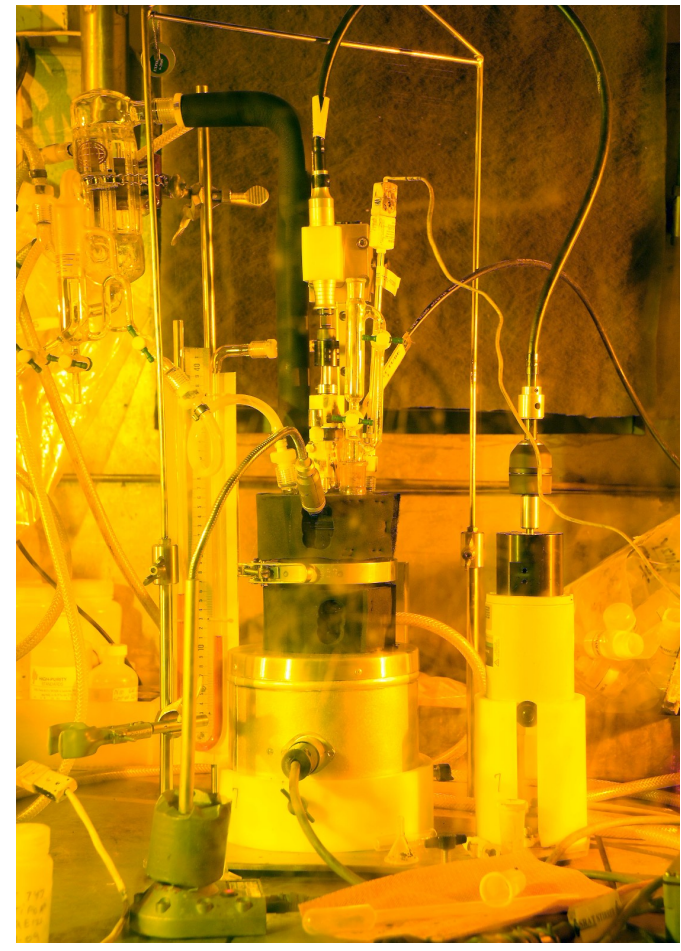

Figure 2. Photograph of SRAT/SME Apparatus in SRNL Shielded Cells 
Offgas hydrogen, oxygen, nitrogen, nitrous oxide, and carbon dioxide concentrations were measured during the experiments using in-line instrumentation (an Agilent M200 series micro GC). Helium was introduced at a concentration of $0.5 \%$ of the total air purge as an inert tracer gas so that total amounts of generated gas and peak generation rates could be calculated. During the runs, the kettle was visually monitored to observe reactions that occurred including foaming, air entrainment, rheology changes, loss of heat transfer capabilities, and offgas carryover. Observations were recorded in laboratory notebooks ${ }^{11,12}$ and are discussed in Sections 4.2 (SRAT cycle) and 4.3 (SME cycle).

Concentrated nitric acid (50-wt $\%)$ and formic acid (90-wt $\%)$ were used to acidify the sludge and perform neutralization and reduction reactions during processing. The amounts of acid to add for each run were determined using the existing DWPF acid addition equation in the 6/1/07 version of the SRNL acid calculation spreadsheet ${ }^{13}$. The split of the acid was determined using the REDOX equation currently being used in DWPF processing ${ }^{14,15}$. To account for the reactions and anion destructions that occur during processing, assumptions about nitrite destruction, nitrite to nitrate conversion, and formate destruction were made. Acid stoichiometry, processing assumptions, and reflux time were based on CPC processing of simulants and current DWPF operations.

With typical Shielded Cells simulations, DWPF design basis parameters are used. However, for this simulation, current DWPF operating parameters were targeted to try to help decrease processing time in DWPF and to provide a better antifoam strategy. Specifically,

- DWPF is feeding formic acid at one gallon per minute (design basis is two gallons per minute), and formic acid addition is paused for thirty minutes between each quarter of formic acid addition to try to minimize offgas pressure surges

- DWPF boilup rate is currently 2,500-3,000 $\mathrm{lb} / \mathrm{h}$ in DWPF compared to the design basis of $5,000 \mathrm{lb} / \mathrm{h}$ because of in-leakage in the vessel vent system.

During the SRAT cycle, samples for $\mathrm{pH}$ measurement and anion and mercury analyses were taken after twelve hours of boiling and every eight hours thereafter. The $\mathrm{pH}$ was requested because of the high $\mathrm{pH}$ SRAT and SME products currently being produced in DWPF, and the goal was to use the anion data to help understand the mechanism for the increased $\mathrm{pH}$. The $\mathrm{Hg}$ data were requested to help determine the minimum required boiling time.

\subsection{RHEOLOGY MEASUREMENTS}

Rheological properties of radioactive samples are determined using a Haake M5/RV30 rotoviscometer. The M5/RV30 is a Searle sensor system, where the bob rotates and the cup is fixed. The torque and rotational speed of the bob are measured. Heating/cooling of the cup/sample/bob is through the cup holder. The shear stress is determined from the torque measurement and is independent of the rheological properties. Conditions that impact the measured torque are; slip (material does not properly adhere to the rotor or cup), phase separation (buildup of liquid layer on rotor), sedimentation (particles settling out of the shearing zone), homogeneous sample (void of air), lack of sample (gap not filled), excess sample (primarily impacts rheologically thin fluids), completely filling up the void below the bob (air buffer that is now filled with fluid) and Taylor vortices. The first five items yield lower stresses 
and the last three add additional stresses. The shear rate is geometrically determined using the equations of change (continuity and motion) and is that for a Newtonian fluid. This approach also assumes that the flow field is fully developed and the flow is laminar. The shear rate can be calculated for non-Newtonian fluid using the measured data and fitting the data to the rheological model or corrected as recommended by Darby ${ }^{16}$. In either case, for shear thinning nonNewtonian fluids typical of Savannah River Site (SRS) sludge wastes, the corrected shear rates are greater than their corresponding Newtonian shear rates, resulting in a thinner fluid. Correcting the flow curves will not be performed in this task, resulting in a slightly more viscous fluid.

The bob typically used for measuring tank sludge or SRAT product is the MV I rotor. For SME product, the MV II rotor is used to perform the measurements, due to the larger frit particles that are present in the SME product. The MV II has a larger gap to accommodate the larger frit particles. The shape, dimensions, and geometric constants for the MV I and MV II rotors are provided in Table 2 .

Prior to performing the measurements, the rotors and cups are inspected for physical damage. The torque/speed sensors and temperature bath are verified for functional operability using a bob/cup combination with a National Institute of Standards and Technology (NIST) traceable Newtonian oil standard, using the MV I rotor. The resulting flow curves are then fitted as a Newtonian fluid and this calculated viscosity must be within $\pm 10 \%$ of the reported NIST viscosity at a given temperature for the system to be considered functionally operable. A N10 oil standard was used to verify system operability prior to the sludge measurements.

The flow curves for the sludge are fitted to the down curves using the Bingham Plastic rheological model, Equation 1, where $\tau$ is the measured stress $(\mathrm{Pa}), \tau_{\mathrm{o}}$ is the Bingham Plastic yield stress $(\mathrm{Pa}), \mu_{\infty}$ is the plastic viscosity $(\mathrm{Pa} \cdot \mathrm{sec})$, and $\dot{\gamma}$ is the measured shear rate $\left(\mathrm{sec}^{-1}\right)$. During all these measurements, the sample remained in the cup for the $2^{\text {nd }}$ measurement, due to the sample availability.

Equation 1

$$
\tau=\tau_{o}+\mu_{\infty} \dot{\gamma}
$$

Table 2. MV I and MV II Rotor Specifications and Flow Curve Program

\begin{tabular}{|c|c|c|c|}
\hline Rotor Design & \multicolumn{3}{|c|}{ Dimensions and Flow Curve Program } \\
\hline & Rotor Type & MV I & MV II \\
\hline & Rotor radius $-\mathrm{R}_{\mathrm{i}}(\mathrm{mm})$ & 20.04 & 18.40 \\
\hline & Cup Radius - $\mathrm{R}_{\mathrm{a}}(\mathrm{mm})$ & 21.0 & 21.0 \\
\hline & Height of rotor $-\mathrm{L}(\mathrm{mm})$ & 60 & 60 \\
\hline & $\begin{array}{l}\text { Sample Volume }\left(\mathrm{cm}^{3}\right) \\
\text { minimum }\end{array}$ & 40 & 55 \\
\hline & A factor $(\mathrm{Pa} / \%$ torque $)$ & 3.22 & 3.76 \\
\hline & $\mathrm{M}$ factor $\left(\mathrm{s}^{-1} / \% \mathrm{RPM}\right)$ & 11.7 & 4.51 \\
\hline & Shear rate range $\left(\mathrm{s}^{-1}\right)$ & $0-600$ & $0-300$ \\
\hline & Ramp up time (min) & 5 & 5 \\
\hline & Hold time (min) & 1 & 1 \\
\hline & Ramp down time (min) & 5 & 5 \\
\hline
\end{tabular}




\subsection{RESULTS AND DISCUSSION}

The primary focus of this report is presentation and discussion of the DWPF simulation using SB5 - Tank 40 adjusted to incorporate an H-Canyon Materials Disposition $\mathrm{Np}$ stream. Comparisons are made between this simulation and the SB5 qualification simulation. To distinguish between these two simulations, the following designations are used:

- SC-6: Shielded Cells DWPF CPC simulation using SB5 qualification sample (Tank 51)

- SC-8: Shielded Cells DWPF CPC demonstration using SB5 material (Tank 40) with decant and additions (primarily a Np stream from H Canyon) based on Tank Farm projections

\subsection{SRAT RECEIPT PREPARATION}

Presented in Table 3 are the characterization results of the SC-8 SRAT receipt (following decant and additions).

Table 3. Characterization Results of the SRAT Receipt Sample

\begin{tabular}{|c|c|c|}
\hline Measurement & $\begin{array}{c}\text { SC-8 (SB5 Run w/ Tank } \\
40 \& \text { Np) }\end{array}$ & $\%$ RSD, $\mathbf{n}$ * \\
\hline Slurry Density (g/mL slurry) & 1.11 & $1.2,4$ \\
\hline Supernatant Density (g/mL supernatant) & 1.05 & 0.74 \\
\hline Total Solids (wt $\%$ of slurry) & 16.0 & $0.4,4$ \\
\hline Dissolved Solids (wt $\%$ of supernate) & 5.6 & $1.3,4$ \\
\hline Insoluble Solids (wt $\%$ of slurry) & 11.0 & NA \\
\hline Soluble Solids (wt $\%$ of slurry) & 5.0 & NA \\
\hline Calcined Solids (wt $\%$ of slurry) & 12.6 & $0.9,4$ \\
\hline Nitrite (mg/kg slurry) & 14,600 & $1.0,4$ \\
\hline Nitrate (mg/kg slurry) & 7,300 & $0.9,4$ \\
\hline $\begin{array}{l}\text { Total Inorganic Carbon (TIC) } \mathrm{mg} / \mathrm{kg} \\
\text { slurry }\end{array}$ & 828 & $6.2,4$ \\
\hline Total Base $\mathrm{mol} / \mathrm{L}$ slurry to $\mathrm{pH}=7$ & 0.43 & $0.3,2$ \\
\hline
\end{tabular}

$\% \mathrm{RSD}=\%$ relative standard deviation; $\mathrm{n}=$ number of replicate analyses. Insoluble and soluble solids are calculated from the average measured total and dissolved solids, thus, the \%RSD and number of replicates is not applicable. 
Table 4 shows a comparison between Tank 40 projections and the SC-8 SRAT receipt material. The SC-8 supernatant nitrite and nitrate values were calculated using the data from Table 3, and assuming that the nitrite and nitrate are all soluble:

Equation 2

$$
C_{i}=X_{i} \cdot \frac{D_{\text {sup }}}{\left(1-W_{i s}\right) \cdot M W_{i} \cdot 1000}
$$

where

$\mathrm{C}_{\mathrm{i}}=$ concentration of component $\mathrm{i}$ in $\mathrm{mol} / \mathrm{L}$ supernatant

$\mathrm{X}_{\mathrm{i}}=$ concentration of component $\mathrm{i}$ in $\mathrm{mg} / \mathrm{kg}$ slurry

$\mathrm{D}_{\text {sup }}=$ density of the supernatant in $\mathrm{kg} / \mathrm{L}$ (equivalent to $\mathrm{g} / \mathrm{mL}$ )

$\mathrm{W}_{\text {is }}=$ weight fraction of insoluble solids $\left(1-\mathrm{W}_{\text {is }}=\right.$ weight fraction supernatant $)$

$\mathrm{MW}_{\mathrm{i}}=$ molecular weight of component $\mathrm{i}$ in $\mathrm{g} / \mathrm{mol}$

$1000=$ conversion factor for $\mathrm{mg}$ to $\mathrm{g}$.

As can be seen in the table, the SRAT receipt sample results are comparable or exceed Tank Farm projections with the exception of nitrate. Because nitrate does not contribute directly to the SRAT cycle acid demand, SRNL proceeded with processing.

Table 4. Comparison of Selected Tank Farm Projections to SC-8 SRAT Receipt

\begin{tabular}{|l|c|c|}
\hline & $\begin{array}{c}\text { Tank Farm } \\
\text { Projection }\end{array}$ & $\begin{array}{c}\text { SC-8 SRAT } \\
\text { Receipt }\end{array}$ \\
\hline Slurry Density (g/mL slurry) & 1.12 & 1.11 \\
\hline Supernatant Density (g/mL supernatant) & 1.04 & 1.05 \\
\hline Total Solids (wt\% of slurry) & 15.7 & 16.0 \\
\hline Insoluble Solids (wt\% of slurry) & 10.3 & 11.0 \\
\hline Nitrite (mol/L supernatant) & 0.35 & 0.37 \\
\hline Nitrate (mol/L supernatant) & 0.18 & 0.14 \\
\hline
\end{tabular}

From Tank Farm planning spreadsheet SB456_010809B.xls 


\subsubsection{Acid Calculation}

Acid calculation inputs for the SC-8 SRAT and SME cycles are presented in Table 5. Inputs for the SC-6 cycles are also included. As can be seen in the table, SC-8 nitrite is 1.7 times more than SC-6, while SC-6 total base is 1.7 times greater than SC-8 and SC-6 total inorganic carbon (TIC) is 1.5 times greater than $\mathrm{SC}-8$. These results show that the total base, primarily hydroxide, and TIC have been "diluted" by nitrite in the SC-8 sample.

Table 5. SC-6 and SC-8 Acid Calculation Inputs

\begin{tabular}{|c|c|c|c|}
\hline Measurement/Assumption & Units & $\begin{array}{l}\text { SC-6 (SB5 } \\
\text { Qual Run) }\end{array}$ & $\begin{array}{c}\text { SC-8 (SB5 Run } \\
\text { w/ Tank } 40 \& \\
\text { Np) }\end{array}$ \\
\hline Total Solids & $\mathrm{wt} \%$ of slurry & 17.1 & 16.0 \\
\hline Insoluble Solids & wt $\%$ of slurry & 11.2 & 11.0 \\
\hline Soluble Solids & $\mathrm{wt} \%$ of slurry & 5.9 & 5.0 \\
\hline Calcined Solids & $\mathrm{wt} \%$ of slurry & 14.0 & 12.6 \\
\hline Slurry Density & $\mathrm{g} / \mathrm{mL}$ slurry & 1.14 & 1.11 \\
\hline Supernatant Density & $\mathrm{g} / \mathrm{mL}$ supernatant & 1.06 & 1.05 \\
\hline $\mathrm{Hg}$ & $\mathrm{wt} \%$ of total solids & 2.22 & 1.75 \\
\hline $\mathrm{Mn}$ & $\mathrm{wt} \%$ of total solids & 4.48 & 3.37 \\
\hline Nitrite & $\mathrm{mg} / \mathrm{kg}$ slurry & 8,660 & 14,600 \\
\hline Nitrate & $\mathrm{mg} / \mathrm{kg}$ slurry & 6,220 & 7,300 \\
\hline Total Inorganic Carbon (TIC) & $\mathrm{mg} / \mathrm{kg}$ slurry & 1,280 & 828 \\
\hline Total Base & $\mathrm{mol} / \mathrm{L}$ slurry to $\mathrm{pH}=7$ & 0.739 & 0.43 \\
\hline $\begin{array}{l}\text { Conversion of Nitrite to Nitrate in } \\
\text { SRAT Cycle }\end{array}$ & $\mathrm{gmol} \mathrm{NO}_{3}^{-} / 100 \mathrm{gmol} \mathrm{NO}_{2}^{-}$ & 0 & 15 \\
\hline $\begin{array}{l}\text { Destruction of Nitrite in SRAT and } \\
\text { SME cycle }\end{array}$ & $\%$ of starting nitrite & 100 & 100 \\
\hline $\begin{array}{l}\text { Destruction of Formic acid charged in } \\
\text { SRAT }\end{array}$ & $\%$ of total formate & 25 & 40 \\
\hline $\begin{array}{l}\text { Percent Acid in Excess of } \\
\text { Stoichiometric Ratio }\end{array}$ & $\%$ & 130 & 145 \\
\hline SRAT Product Target Total Solids & $\mathrm{wt} \%$ of SRAT Product & 25 & 20 \\
\hline Predicted or Target REDOX & $\mathrm{Fe}^{+2} / \Sigma \mathrm{Fe}$ & 0.20 & 0.12 \\
\hline Destruction of Formic acid in SME & $\%$ of SRAT Product formate & 10 & 10 \\
\hline Destruction of Nitrate in SME & $\%$ of SRAT Product nitrate & 10 & 10 \\
\hline $\begin{array}{l}\text { Sludge Oxide Contribution in SME } \\
\text { (Waste Loading) }\end{array}$ & $\%$ sludge oxides & 34 & 34 \\
\hline SME Product Target Total Solids & wt $\%$ of SME Product & 45 & 45 \\
\hline
\end{tabular}


Acid calculation outputs for runs SC-6 and SC-8 are presented in Table 6. In comparing the stoichiometric acid requirements, the SC-6 SRAT cycle required 32\% more acid This amount is consistent with the acid calculation inputs, specifically the lower total base and carbonate (as measured by TIC) in the SC-8 SRAT receipt. Although nitrite is substantially higher in SC-8, its acid demand $(0.75 \mathrm{~mol} \mathrm{acid} / \mathrm{mol}$ nitrite $)$ is more than offset by the decrease in total base and TIC ( $1 \mathrm{~mol} \mathrm{acid} / \mathrm{mol}$ total base and $2 \mathrm{~mol} \mathrm{acid} / \mathrm{mol}$ carbonate calculated from TIC).

Table 6. SC-6 and SC-8 Acid Calculation Results

\begin{tabular}{|l|c|c|}
\hline \multicolumn{1}{|c|}{ Parameter } & $\begin{array}{c}\text { SC-6 (SB5 } \\
\text { Qual Run) }\end{array}$ & $\begin{array}{c}\text { SC-8 (SB5 Run w/ } \\
\text { Tank 40 \& Np) }\end{array}$ \\
\hline $\begin{array}{l}\text { Calculated Stoichiometric Acid (100\% } \\
\text { stoichiometry), moles/L - Hsu } \\
\text { equation }\end{array}$ & 1.32 & 0.99 \\
\hline $\begin{array}{l}\text { Actual Acid to Add (130\% } \\
\text { stoichiometry for SC-6, 145\% for } \\
\text { SC-8), moles/L }\end{array}$ & 1.72 & 1.44 \\
\hline Ratio of Formic Acid to Total Acid & 0.85 & 0.88 \\
\hline \multicolumn{2}{|c|}{ Stoichiometric acid amount by input (mol/L slurry) } \\
\hline Mercury & 0.02 & 0.02 \\
\hline Manganese & 0.16 & 0.13 \\
\hline Nitrite & 0.16 & 0.26 \\
\hline Total Inorganic Carbon (TIC) & 0.24 & 0.15 \\
\hline Total Base & 0.74 & 0.43 \\
\hline
\end{tabular}




\subsection{SRAT CYCLE}

During the SRAT cycle, there were no issues or problems with mixing, concentration (water removal), or maintaining the target boilup rate. Note that SRAT and SME foaming along with antifoam additions is discussed in Section 4.4.

Throughout the SRAT cycle (twelve hours after boiling began and every eight hours thereafter) samples were pulled. The final SRAT product (after 44 hours of boiling) was measured for density, total solids, anions, and $\mathrm{pH}$. Results, averages of four measurements with the exception of $\mathrm{pH}$, and the calculated values of insoluble and soluble solids are presented in Table 7. The remaining samples were characterized for anions and mercury (in duplicate) and $\mathrm{pH}$ to try to understand the cause for the rising $\mathrm{pH}$ and to determine the minimum boiling time to remove $\mathrm{Hg}$. The average of these duplicate measurements is presented in Table 8, along with the SRAT product results (44-hour sample). Overall, there was good agreement between the duplicate results with the exception of the $\mathrm{Hg}$ analysis of the 20-hour sample. Relative standard deviations are not given in Table 8 because of space considerations. They are instead presented in Appendix C.

Table 7. Characterization Results of the SC-8 SRAT Product

\begin{tabular}{|l|c|c|}
\hline Analysis & SRAT Product & \%RSD, \\
\hline Slurry Density (g/mL) & 1.13 & $0.1,4$ \\
\hline Supernatant Density (g/mL) & 1.06 & $0.7,4$ \\
\hline Weight \% Total Solids (slurry basis) & 19.3 & $0.6,4$ \\
\hline Weight \% Dissolved Solids (supernatant basis) & 9.7 & $0.6,4$ \\
\hline Weight \% Insoluble Solids (slurry basis) & 10.6 & $\mathrm{NA}$ \\
\hline Weight \% Soluble Solids (slurry basis) & 8.7 & $\mathrm{NA}$ \\
\hline Weight \% Calcined Solids (slurry basis) & 14.3 & $0.5,4$ \\
\hline Nitrite (mg/kg slurry) & $<740$ & $\mathrm{NA}$ \\
\hline Nitrate (mg/kg slurry) & 29,800 & $2.3,4$ \\
\hline Formate (mg/kg slurry) & 37,200 & $3.3,4$ \\
\hline TIC (mg/kg slurry) & $<191$ & $\mathrm{NA}$ \\
\hline pH & 8.74 & $\mathrm{NA}, 1$ \\
\hline
\end{tabular}

Table 8. Anions, Mercury, and pH of the SC-8 Periodic Samples

\begin{tabular}{|l|c|c|c|c|c|}
\hline \multirow{2}{*}{} & \multicolumn{5}{|c|}{ Time at Boiling (h) } \\
\cline { 2 - 6 } & $\mathbf{1 2}$ & $\mathbf{2 0}$ & $\mathbf{2 8}$ & $\mathbf{3 6}$ & $\mathbf{4 4}$ \\
\hline Formate $(\mathrm{mg} / \mathrm{kg})$ & 44,600 & 42,900 & 40,000 & 39,100 & 37,200 \\
\hline Nitrite $(\mathrm{mg} / \mathrm{kg})$ & $<730$ & $<750$ & $<819$ & $<800$ & $<740$ \\
\hline Nitrate $(\mathrm{mg} / \mathrm{kg})$ & 30,800 & 31,200 & 30,800 & 31,700 & 29,800 \\
\hline Mercury $(\mathrm{wt} /$ of total solids) & 0.96 & 0.60 & 0.21 & 0.12 & 0.10 \\
\hline $\mathrm{pH}$ & 7.89 & 8.08 & 8.32 & 8.56 & 8.74 \\
\hline
\end{tabular}




\subsubsection{Nitrite Destruction and Mercury Removal}

The results for formate, nitrate, $\mathrm{pH}$, and mercury from Table 8 are presented graphically in Figure 3 and Figure 4. Because nitrite is below detection limits and below the SRAT product limit of $1,000 \mathrm{mg} / \mathrm{kg}$ for all samples, it is not plotted.

Figure 3 shows clearly that minimal variation in nitrate concentration existed after twelve hours of boiling. That is, nitrate is not destroyed during the long boiling time. Formate, however, shows a decrease of nearly $17 \%$ between twelve hours and the completion of the SRAT cycle. This formate destruction corresponds to the increase in $\mathrm{pH}$ throughout boiling.

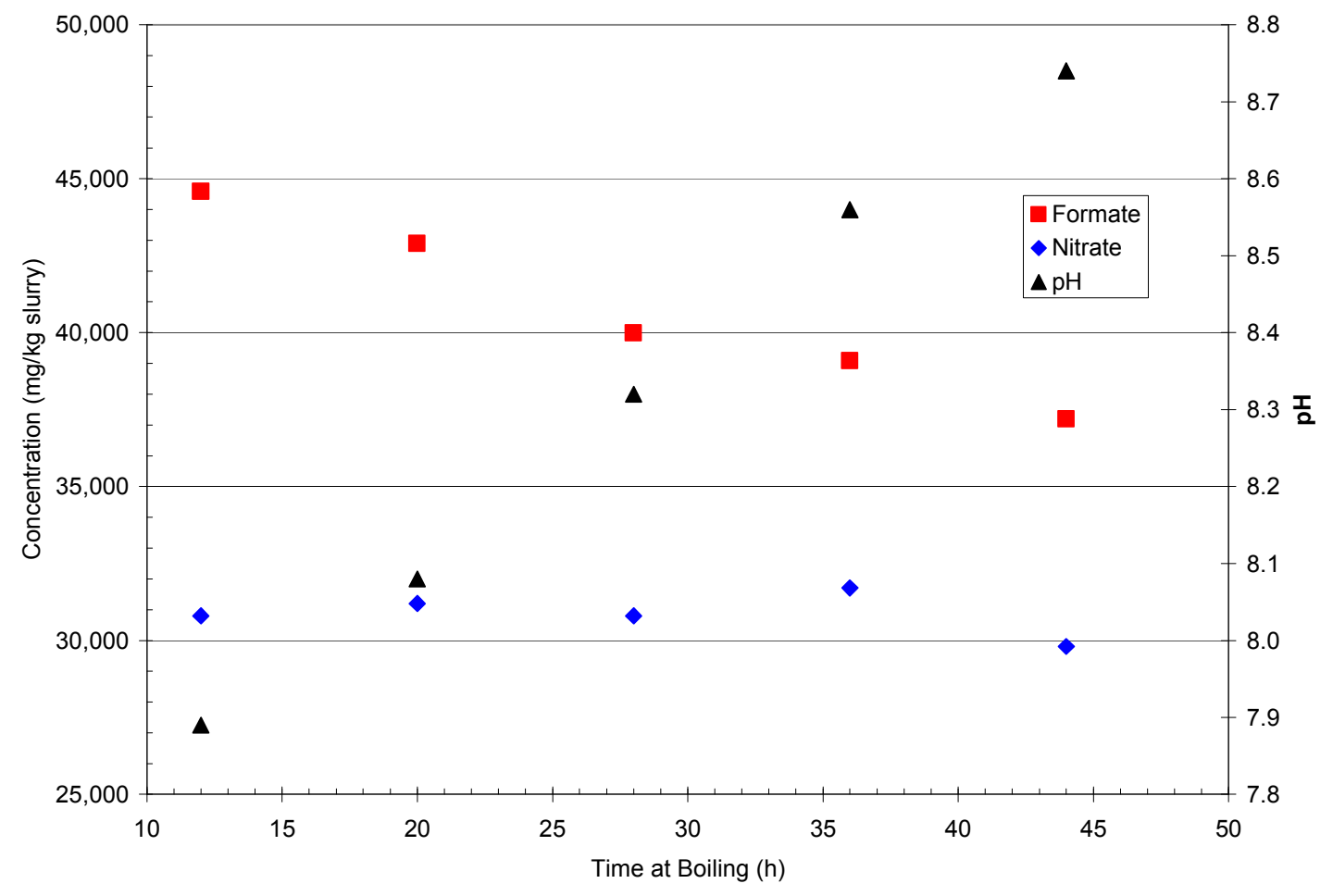

Figure 3. Formate, Nitrate, and pH as a function of SC-8 SRAT Cycle Boiling Time 
Mercury concentration in the total solids as a function of time at boiling can be approximated by an exponential decay. MS Excel's Trendline feature was used to draw the exponential curve (solid line) in Figure 4. The correlation coefficient $\left(\mathrm{R}^{2}\right)$ of this curve fit is 0.96. Based on the measured mercury in the total solids, mercury concentration falls below the DWPF limit within 28 hours of boiling. If one uses the Trendline, it appears the mercury limit is reached within 22 hours of boiling.

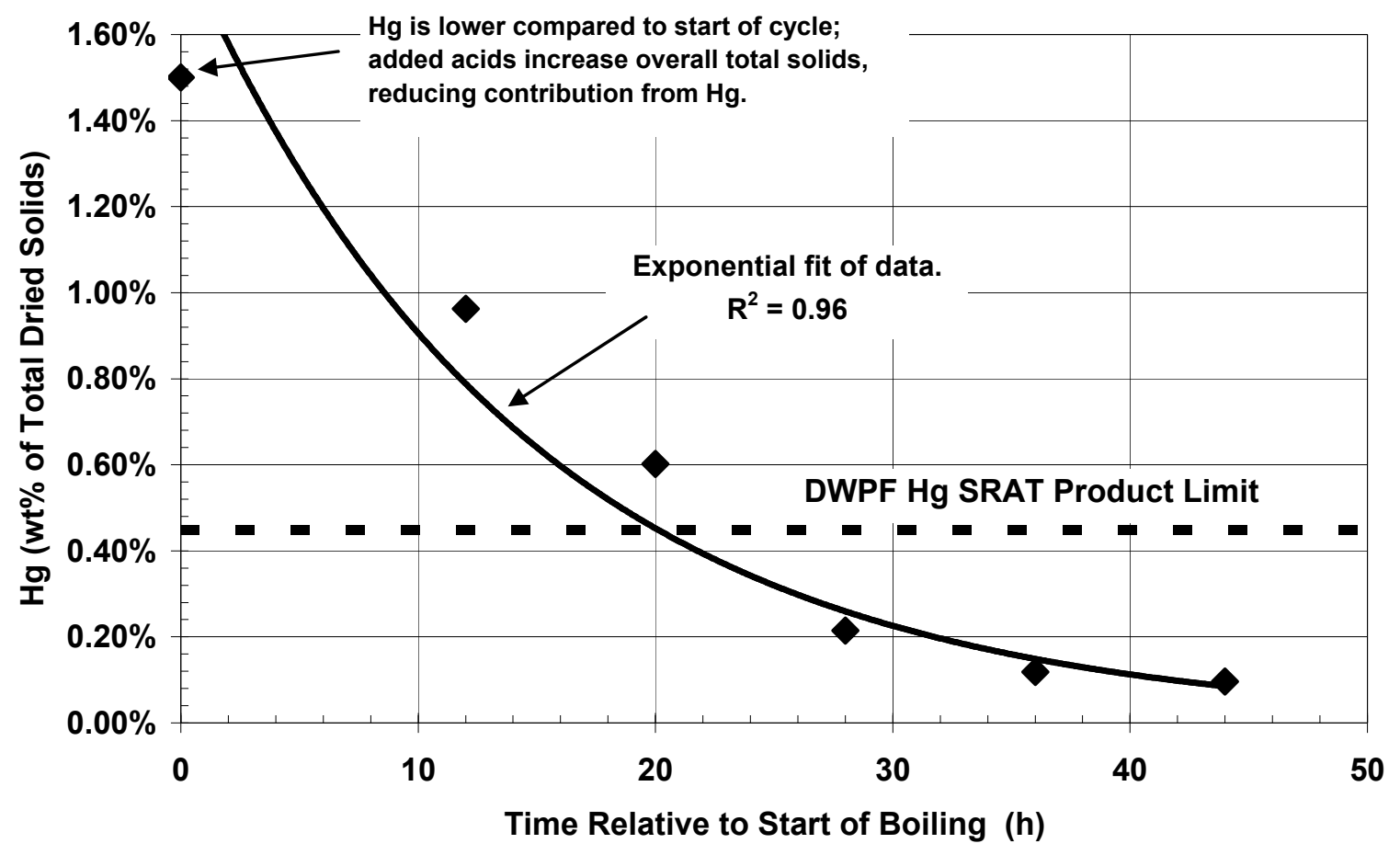

Figure 4. Mercury Content of Total Solids as a Function of SC-8 SRAT Cycle Boiling Time 


\subsection{SME CYCLE}

Like the SRAT cycle, during the SME cycle, there were no issues or problems with mixing, concentration (water removal), or maintaining the target boilup rate. At the conclusion of the SME cycle, a sample for analysis was taken. Weight percent solids, density, anions, TIC, Total Organic Carbon (TOC), and $\mathrm{pH}$ were measured. Results are presented in Table 9. Note that SRAT and SME foaming along with antifoam additions is discussed in Section 4.4.

Table 9. Characterization Results of the SC-8 SME Product

\begin{tabular}{|l|c|c|}
\hline Analysis & SME Product & \%RSD, ${ }^{*}$ \\
\hline Slurry Density (g/mL) & 1.44 & $0.6,4$ \\
\hline Supernatant Density (g/mL) & 1.10 & $0.2,4$ \\
\hline Weight \% Total Solids (slurry basis) & 48.5 & $0.8,4$ \\
\hline Weight \% Dissolved Solids (supernatant basis) & 14.4 & $0.2,4$ \\
\hline Weight \% Insoluble Solids (slurry basis) & 39.9 & $\mathrm{NA}$ \\
\hline Weight \% Soluble Solids (slurry basis) & 8.6 & $\mathrm{NA}$ \\
\hline Weight \% Calcined Solids (slurry basis) & 42.7 & 1.8, \\
\hline Nitrite (mg/kg slurry) & $<770$ & $\mathrm{NA}$ \\
\hline Nitrate (mg/kg slurry) & 29,800 & $3.9,4$ \\
\hline Formate (mg/kg slurry) & 38,500 & $3.7,4$ \\
\hline TIC (mg/kg slurry) & $<192$ & $\mathrm{NA}$ \\
\hline TOC (mg/kg slurry) & 12,100 & $2.0,4$ \\
\hline pH & 8.44 & $\mathrm{NA}, 1$ \\
\hline
\end{tabular}

$\%$ RSD $=\%$ relative standard deviation; $\mathrm{n}=$ number of replicate analyses. Insoluble and soluble solids are calculated from the average measured total and dissolved solids, thus, the \%RSD and number of replicates is not applicable.

\subsection{SRAT AND SME ANTIFOAM ADDITIONS AND FOAMING}

One of the goals of the run was to determine a refined antifoam strategy due to the problems seen with the SB5 qualification run. The following antifoam addition strategy was planned for the SRAT and SME cycles, which represented the minimum antifoam addition strategy and was used for the last several sludge batches in DWPF:

- 200 ppm addition prior to heating

- 500 ppm addition prior to boiling (after formic acid addition)

- 100 ppm every eight hours during boiling

- 100 ppm every eight hours during the SME cycle

Prior to beginning the processing, the decision was made to add antifoam whenever foam was seen in the upper window of the SRAT/SME apparatus (see Figure 2). Also, if the frequency of additions became greater than every four hours, additions of greater than $100 \mathrm{ppm}$ would be used. 
Antifoam additions for the SRAT and SME cycles are summarized in Table 10 and Table 11, respectively. During the early stages of SRAT boiling, antifoam was needed every six to eight hours. Excessive foaming became problematic after 27 hours of boiling, necessitating antifoam additions every one to three hours. This behavior continued into the decon water removal phase of the SME cycle. This result is not surprising, since decon water removal in the SME is in essence boiling/concentration of SRAT material. Following frit/formic acid addition (i.e., during frit water removal and final dewatering), no antifoam was needed.

Table 10. SC-8 SRAT Cycle Antifoam Additions

\begin{tabular}{|c|l|}
\hline $\begin{array}{c}\text { Antifoam Amount } \\
\text { (mg/kg of SRAT } \\
\text { Receipt) }\end{array}$ & \multicolumn{1}{c|}{ Comment } \\
\hline 200 & $\begin{array}{l}\text { Added during first quarter of formic acid addition. Note that this } \\
\text { antifoam should have been added prior to startup; it was not added at } \\
\text { that time due to antifoam addition funnel problems. }\end{array}$ \\
\hline 500 & Added just prior to boiling. \\
\hline 100 & Added after 6 hours of boiling. \\
\hline 100 & Added after 12 hours of boiling. \\
\hline 100 & Added after 20 hours of boiling. \\
\hline 120 & Added after 27 hours of boiling. \\
\hline 100 & Added after 28 hours of boiling. \\
\hline 160 & Added after 33 hours of boiling. \\
\hline 190 & Added after 34 hours of boiling. \\
\hline 180 & Added after 36 hours of boiling. \\
\hline 200 & $\begin{array}{l}\text { Added shortly after previous addition. Previous addition was not } \\
\text { effective. }\end{array}$ \\
\hline 190 & Added after 38 hours of boiling. \\
\hline 220 & Added after 40 hours of boiling. \\
\hline 470 & Added after 42 hours of boiling. \\
\hline 2830 & Total Antifoam Added in SRAT cycle \\
\hline
\end{tabular}

Table 11. SC-8 SME Cycle Antifoam Additions

\begin{tabular}{|c|l|}
\hline $\begin{array}{c}\text { Antifoam Amount } \\
\text { (mg/kg of SME } \\
\text { Receipt) }\end{array}$ & \\
\hline 280 & Added 2 hours after start of SME cycle (during decon water removal). \\
\hline 150 & Added 5 hours after start of SME cycle (during decon water removal). \\
\hline 150 & Added 8 hours after start of SME cycle (during decon water removal). \\
\hline 0 & $\begin{array}{l}\text { No antifoam was required during boiling to remove the frit water or } \\
\text { during the final SME cycle dewatering. }\end{array}$ \\
\hline 580 & Total Antifoam Added in SME cycle \\
\hline
\end{tabular}


Based on these observations, SRNL recommends the following antifoam strategy:

1. $200 \mathrm{ppm}$ prior to SRAT cycle heatup

2. $100 \mathrm{ppm}$ after addition of nitric acid is complete

3. $500 \mathrm{ppm}$ after addition of formic acid is complete

4. 300 ppm every 6 hours of SRAT boiling

5. 300 ppm every 6 hours during canister decon boiling and 100 ppm each 8 hours during the rest of the SME cycle

\subsection{ANION DESTRUCTION AND CONVERSION}

The calculated anion destruction and conversion results for the SC-8 SRAT and SME cycles, with comparisons to the acid calculation input assumptions and the SC-6 simulations are given in Table 12 below. With the exception of nitrite to nitrate conversion, the SC-8 results are comparable to the acid calculation inputs.

Table 12. SC-8 Assumed and Measured Anion Destruction and Conversion with Comparison to SC-6

\begin{tabular}{|l|c|c|c|}
\hline & $\begin{array}{c}\text { Assumption } \\
\text { (SC-8 Acid } \\
\text { Calculation } \\
\text { Input) }\end{array}$ & $\begin{array}{c}\text { SC-6 (SB5 } \\
\text { Qual Run) }\end{array}$ & $\begin{array}{c}\text { SC-8 (SB5 } \\
\text { Run w/ Tank } \\
\mathbf{4 0} \& \text { Np) }\end{array}$ \\
\hline $\begin{array}{c}\text { SRAT Cycle Nitrite Destruction } \\
(\%)\end{array}$ & 100 & $>92$ & $>95$ \\
\hline $\begin{array}{l}\text { SRAT Cycle Formate Destruction } \\
(\%)\end{array}$ & 40 & 18 & 36 \\
\hline $\begin{array}{l}\text { SRAT Cycle Nitrite to Nitrate } \\
\text { Conversion (\%) }\end{array}$ & 15 & $100^{*}$ & 52 \\
\hline $\begin{array}{c}\text { SME Cycle Formate Destruction } \\
(\%)\end{array}$ & 10 & 26 & 32 \\
\hline $\begin{array}{c}\text { SME Cycle Nitrate Destruction } \\
(\%)\end{array}$ & 10 & 32 \\
\hline
\end{tabular}

This conversion is not reasonable based on the fact that nitrous oxide was measured in significant quantities in the offgas. That is, some nitrite was converted to NOx gas. This result is likely due to a combination of analytical errors in the SRAT receipt and product anion analyses and the overall SRAT cycle mass balance. 


\subsection{OFFGAS ANALYSIS}

Peak offgas volume percents and DWPF-scale generation rates are given in Table 13. The offgas data are presented graphically in Figure 5 (SRAT cycle) and Figure 6 (SME cycle). The figures show a typical SRAT/SME cycle pattern: large amounts of carbon dioxide during acid addition, a hydrogen peak several hours after nitrous oxide generation drops, and drops in gas generation rate as the vessel is breached for pulling samples (SRAT cycle) and adding water and frit (SME cycle). In both cycles, peak hydrogen generation was well below DWPF limits.

Table 13. Maximum Observed Hydrogen, Carbon Dioxide, and Nitrous Oxide Volume Percent and DWPF Scale Generation Rates during SC-8 CPC Processing

\begin{tabular}{|c|c|c|c|c|}
\hline \multirow{2}{*}{ Gas } & \multicolumn{2}{|c|}{ SRAT Cycle } & \multicolumn{2}{c|}{ SME Cycle } \\
\cline { 2 - 5 } & $\begin{array}{c}\text { Maximum } \\
\text { Observed } \\
\text { Volume\% }\end{array}$ & $\begin{array}{c}\text { Maximum Gas } \\
\text { Generation Rate } \\
(\mathrm{DWPF} \mathrm{lb} / \mathrm{h})\end{array}$ & $\begin{array}{c}\text { Maximum } \\
\text { Observed } \\
\text { Volume\% }\end{array}$ & $\begin{array}{c}\text { Maximum Gas } \\
\text { Generation Rate } \\
(\mathrm{DWPF} \mathrm{lb} / \mathrm{h})\end{array}$ \\
\hline Hydrogen & 0.29 & 0.24 & 0.51 & 0.15 \\
\hline Carbon Dioxide & 12.2 & 235 & 3.80 & 23.9 \\
\hline Nitrous Oxide & 2.65 & 49.8 & 0.33 & 1.91 \\
\hline
\end{tabular}




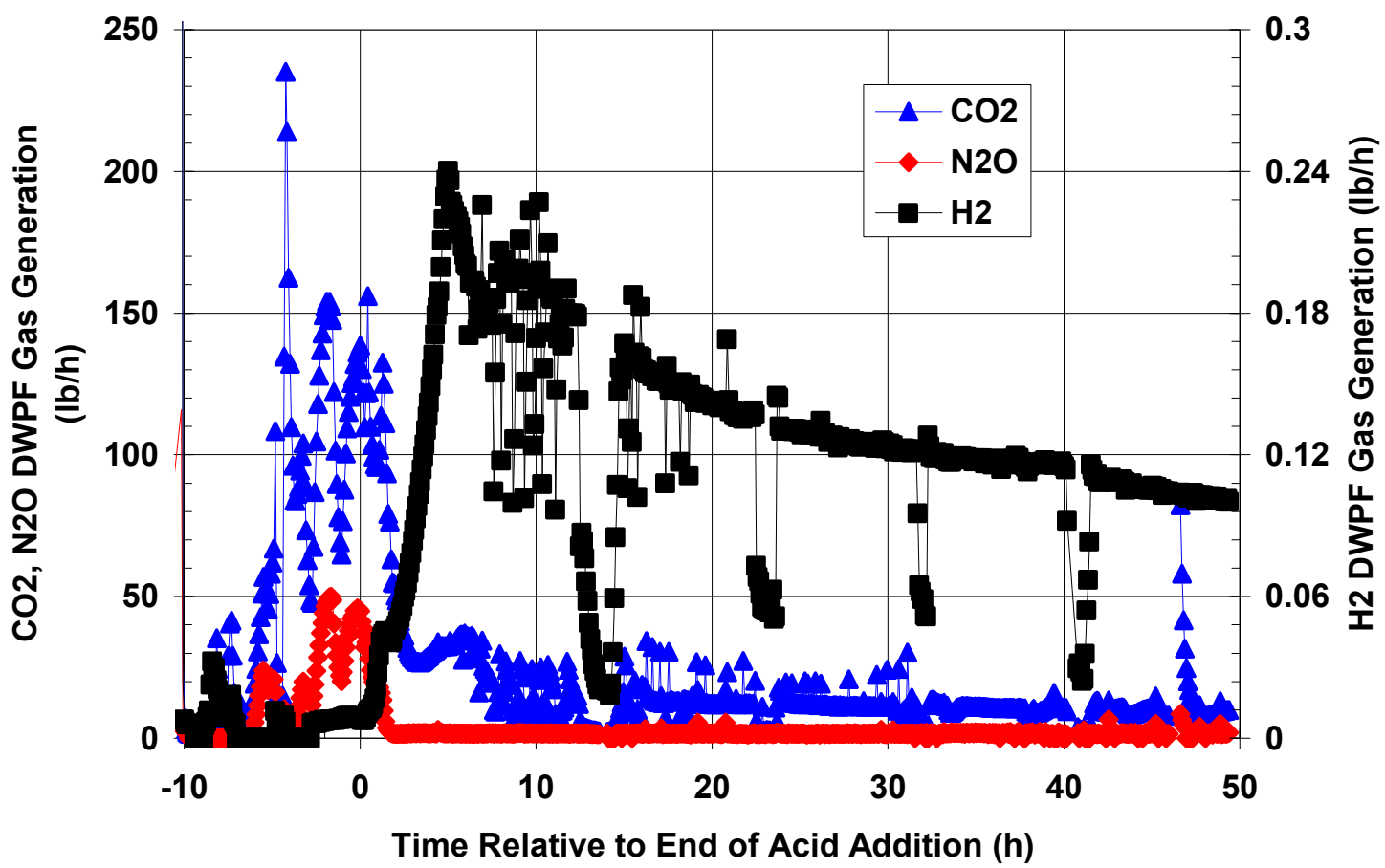

Figure 5. SC-8 SRAT Cycle Offgas Data (DWPF Scale)

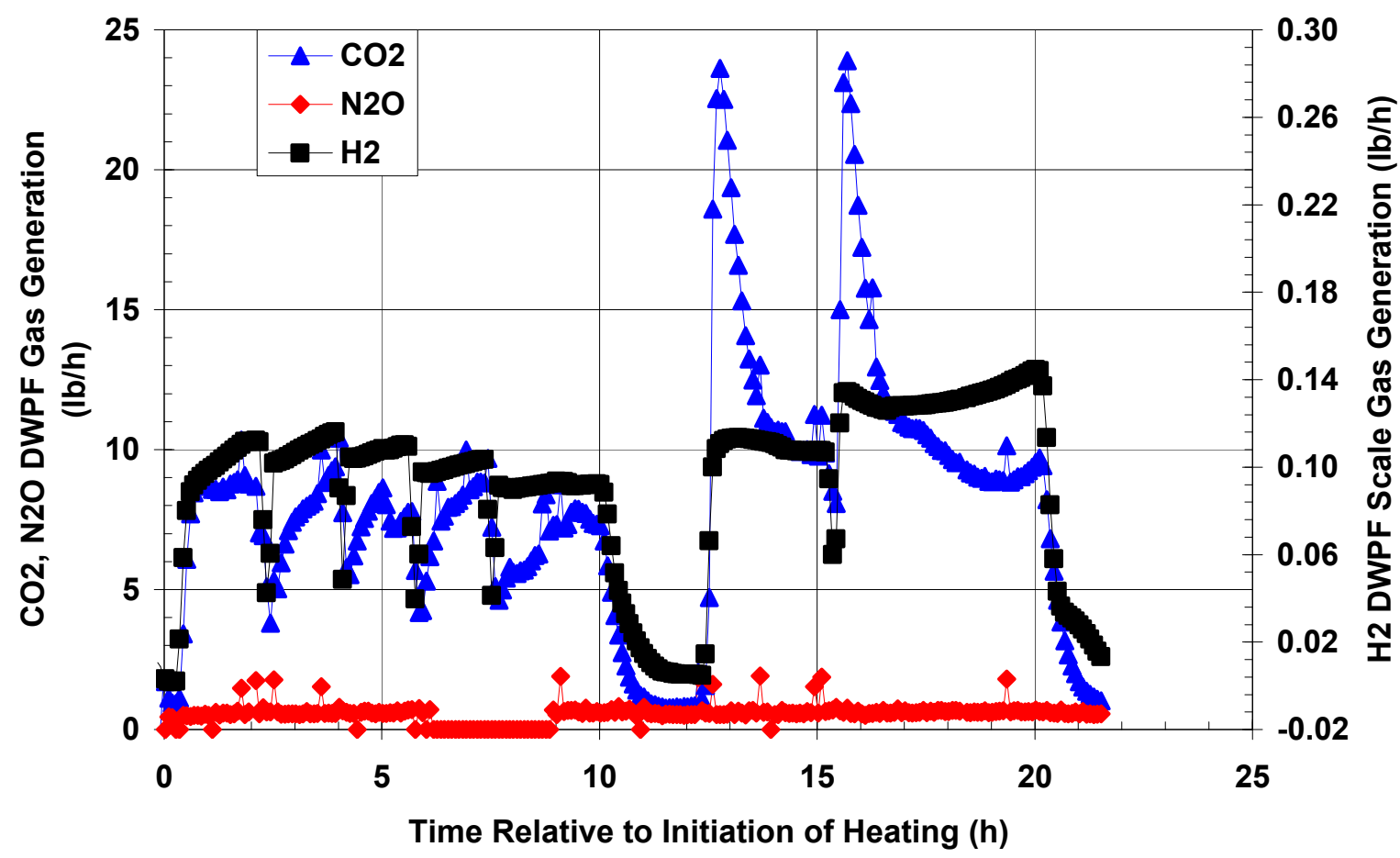

Figure 6. SC-8 SME Cycle Offgas Data (DWPF Scale) 


\subsection{RHEOLOGY MEASUREMENTS}

Given in Table 14 are the results of rheology measurements (yield stress and consistency) for the SC-8 slurry samples (SRAT receipt, SRAT product, and SME product).

Table 14. Rheology Measurements of SC-8 SRAT Receipt, SRAT Product, and SME Product

\begin{tabular}{|l|c|c|c|c|c|}
\hline & $\begin{array}{c}\text { Insoluble } \\
\text { Solids } \\
\text { (wt\%) }\end{array}$ & $\begin{array}{c}\text { Yield } \\
\text { Stress (Pa) }\end{array}$ & $\begin{array}{c}\text { Consistency } \\
\text { (cP) }\end{array}$ & $\begin{array}{c}\text { DWPF Design } \\
\text { Basis Yield } \\
\text { Stress (Pa) }\end{array}$ & $\begin{array}{c}\text { DWPF Design } \\
\text { Basis } \\
\text { Consistency } \\
\text { (cP) }\end{array}$ \\
\hline $\begin{array}{c}\text { SC-8 SRAT } \\
\text { Receipt) }\end{array}$ & 11.0 & 5.2 & 6.9 & $2.5-10$ & $4-12$ \\
\hline $\begin{array}{c}\text { SC-8 SRAT } \\
\text { Product (19.3 } \\
\begin{array}{l}\text { wt\% total } \\
\text { solids) }\end{array}\end{array}$ & 10.6 & 6.4 & 14 & $1.5-5.0$ & $5-12$ \\
\hline $\begin{array}{l}\text { SC-8 SME } \\
\text { Product (48.5 } \\
\text { wt\% total } \\
\text { solids) }\end{array}$ & $39.9 *$ & 38 & 9.6 & $2.5-15$ & $10-40$ \\
\hline
\end{tabular}

Design bases can be found in Reference 17.

* The SME product material used for rheology was taken from the contents of the SRAT/SME vessel several weeks after the run. It is likely the $\mathrm{wt} \%$ solids are higher than the SME analytical sample, analyzed immediately after the cycle. An attempt was made to measure the wt $\%$ solids of this material, but the results were lower than a sample diluted with water, implying a sub-sampling problem.

Because of the high yield stress of the SC-8 SME product, SME product samples at various weight percent solids were prepared and rheological properties were measured to provide data for a recommended SME product total solids target. These results are presented in Table 15 and Figure 7. As can be seen in the results, yield stress is a strong function of solids content; yield stress increases dramatically as $\mathrm{wt} \%$ total solids increase beyond $43 \%$

Table 15. Rheology of SC-8 SME Product at Various Weight Percent Total Solids

\begin{tabular}{|c|c|c|}
\hline Wt\% Total Solids & $\begin{array}{c}\text { Yield Stress } \\
\text { (Pa) }\end{array}$ & $\begin{array}{c}\text { Consistency } \\
\text { (cP) }\end{array}$ \\
\hline 40.0 & 8.8 & 5.8 \\
\hline 42.9 & 9.9 & 5.7 \\
\hline 47.5 & 21 & 9.0 \\
\hline $48.5^{\ddagger}$ & 38 & 9.7 \\
\hline
\end{tabular}

* The SME product material used for rheology was taken from the contents of the SRAT/SME vessel several weeks after the run. It is likely the wt $\%$ solids are higher than the SME analytical sample, analyzed immediately after the cycle. An attempt was made to measure the $\mathrm{wt} \%$ solids of this material, but the results were lower than a sample diluted with water, implying a sub-sampling problem. 
SRNS-STI-2009-00233, REVISION 0

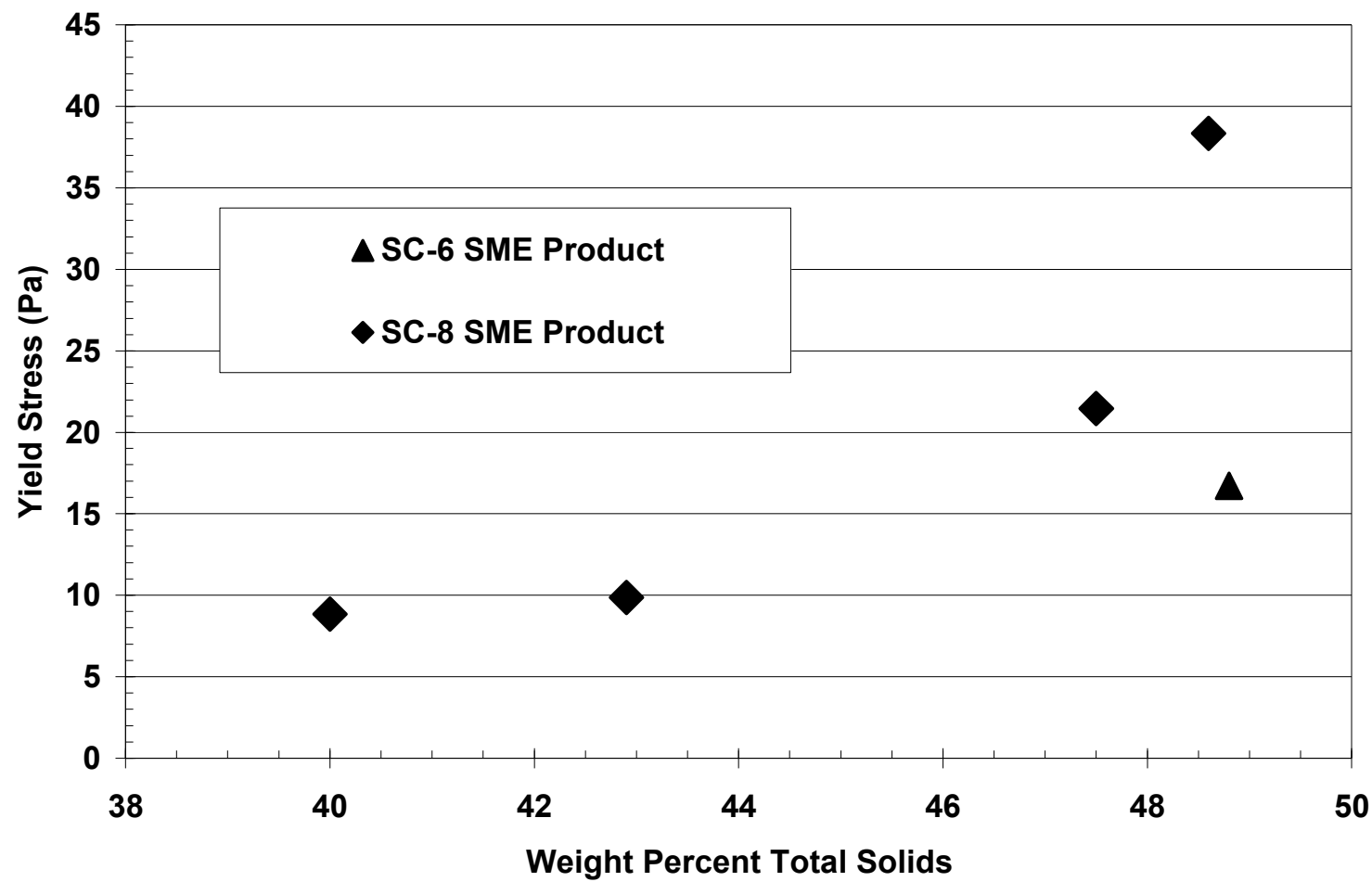

Figure 7. Graphical presentation of SME Product Yield Stress Results 
Table 16 shows a comparison between SC-6 and SC-8 material. These results and comparisons show that:

- The SC-8 SRAT product yield stress and consistency exceed DWPF design bases, but the results are fairly close to the measured values for the SB5 SRAT cycle (SC-6).

- Yield stress of the SC-8 SME product is significantly higher than the corresponding SC-6 material even with comparable $\mathrm{wt} \%$ total and insoluble solids (see also graphical comparison in Figure 7). However, the yield stress can be significantly lowered by decreasing SME product solids content.

These differences in rheological properties between SC-6 and SC-8 are likely a result of the differences in acid added in the respective SRAT cycles $(1.72 \mathrm{~mol} / \mathrm{L}$ for SC-6 and $1.44 \mathrm{~mol} / \mathrm{L}$ for $\mathrm{SC}-8)$.

Table 16. Comparison Between SC-6 and SC-8 SRAT Receipt, SRAT Product, and SME Product

\begin{tabular}{|l|c|c|c|c|c|}
\hline & & $\begin{array}{c}\text { Weight \% } \\
\text { Total Solids }\end{array}$ & $\begin{array}{c}\text { Weight \% } \\
\text { Insoluble } \\
\text { Solids }\end{array}$ & $\begin{array}{c}\text { Yield Stress } \\
\text { (Pa) }\end{array}$ & $\begin{array}{c}\text { Consistency } \\
\text { (cP) }\end{array}$ \\
\hline \multirow{2}{*}{ SRAT Receipt } & SC-6 & 17.1 & 11.2 & 6.8 & 8.6 \\
\cline { 2 - 6 } & SC-8 & 16.0 & 11.0 & 5.2 & 6.9 \\
\hline \multirow{2}{*}{ SRAT Product } & SC-6 & $20^{*}$ & $11.3^{*}$ & 6.4 & 6.1 \\
\cline { 2 - 6 } & SC-8 & 19.3 & 10.6 & 6.4 & 14 \\
\hline \multirow{2}{*}{ SME Product } & SC-6 & 48.8 & 40.3 & 16.7 & 13.8 \\
\cline { 2 - 6 } & SC-8 & $48.5^{\dagger}$ & $39.9^{\dagger}$ & 38 & 9.6 \\
\hline
\end{tabular}

This is an estimate. Dewater from the SC-6 SRAT cycle was added back to a portion of an SC-6 SRAT product sample to produce a sample at $20 \%$ total solids. The total solids were not measured.

$\dagger$ The SME product material used for rheology was taken from the contents of the SRAT/SME vessel several weeks after the run. It is likely the $\mathrm{wt}^{\%} \%$ solids are higher than the SME analytical sample, analyzed immediately after the cycle. An attempt was made to measure the wt\% solids of this material, but the results were lower than a sample diluted with water, implying a sub-sampling problem. 


\subsection{CONCLUSIONS}

The DWPF can process Tank 40 following a decant and addition of sodium nitrite and a Npbearing stream from $\mathrm{H}$ Canyon. The SRNL simulations showed that:

- The DWPF hydrogen generation limits in the SRAT and SME cycles were not exceeded.

- Less acid was needed for the SC-8 SRAT cycle (Tank 40 with Np) compared to the qualification SRAT cycle (SC-6) due to "dilution" of total base because of the addition of nitrite and nitrate. Note that in the acid calculation, $1 \mathrm{~mol}$ of acid is required for each mol of total base (predominantly hydroxide), while $0.75 \mathrm{~mol}$ of acid is required per mol of nitrite.

- Nitrite was destroyed to below DWPF limits within twelve hours of boiling in the SRAT cycle.

- Mercury was removed to below DWPF limits within 28 hours of boiling in the SRAT cycle at a boilup rate of $2,500 \mathrm{lb} / \mathrm{h}$.

- During the long boiling period, formate concentration decreased as $\mathrm{pH}$ increased.

- The SRAT (and SME during canister decon dewatering) was prone to foaming as boiling progressed; however, the antifoam was effective at suppressing the foam layer when added.

- Although rheological properties of SRAT and SME products exceeded DWPF design bases, SRNL had no difficulties in mixing or heating these materials. Rheological properties of the SC-8 SRAT product was comparable to the SB5 qualification SRAT product, but the yield stress of the SC- 8 SME product greatly exceeded the SC-6 SME product. 


\subsection{RECOMMENDATIONS}

Based on these simulations, SRNL recommends:

- SRAT product solids concentration target of no greater than $20 \mathrm{wt} \%$ total solids

- SRAT boiling time (dewater plus reflux) of 28 hours at $2,5000 \mathrm{lb} / \mathrm{hr}$ steam $(70,000 \mathrm{lb}$ of steam total) to ensure $\mathrm{Hg}$ reduction

- SME product concentration to no greater than $45 \mathrm{wt} \%$ total solids

- The following antifoam addition strategy:

○ 200 ppm prior to SRAT cycle heatup

- $100 \mathrm{ppm}$ after addition of nitric acid is complete

○ $\quad 500 \mathrm{ppm}$ after addition of formic acid is complete

○ $\quad 300$ ppm every 6 hours of SRAT boiling

○ $\quad 300$ ppm every 6 hours during canister decon boiling and 100 ppm each 8 hours during the rest of the SME cycle 


\subsection{REFERENCES}

1. Pareizs, J. M.; Bannochie, C. J.; Click, D. R.; Lambert, D. P.; Stone, M. E.; Pickenheim, B. R.; Billings, A. L.; Bibler, N. E. Sludge Washing and Demonstration of the DWPF Flowsheet in the SRNL Shielded Cells for Sludge Batch 5 Qualification; WSRC-STI-2008-00111; Savannah River National Laboratory: Aiken, SC, 2008.

2. Pareizs, J. M.; Pickenheim, B. R.; Bannochie, C. J. Data from the SC-8 DWPF CPC Simulation (Sludge Batch 5 With H Canyon Neptunium); SRNL-L3100-2009-00051; Savannah River National Laboratory: Aiken, SC, 2009.

3. Pareizs, J. M.; Pickenheim, B. R.; Bannochie, C. J. Mercury Results from the SC-8 SRAT Cycle (DWPF CPC Simulation Using Sludge Batch 5 With H Canyon Neptunium); SRNLL3100-2009-00055; Savannah River National Laboratory: Aiken, SC, 2009.

4. Fellinger, T. L. Sludge Batch 5 SRNL Shielded Cells Testing: Technical Task Request; HLWDWPF-TTR-2008-0010, Rev. 2; Savannah River Site: Aiken, SC, 2008.

5. Bannochie, C. J.; Pareizs, J. M. Qualification of DWPF Sludge Batch 5 (Macrobatch 6) in the SRNL Shielded Cells: Task Technical \& Quality Assurance Plan; WSRC-RP-2008-00137, Rev. 2; Savannah River National Laboratory: Aiken, SC, 2008.

6. Bannochie, C. J. Qualification of DWPF Sludge Batch 5 in the SRNL Shielded Cells: Analytical Study Plan; WSRCRP-2008-00138, Rev. 2; Savannah River National Laboratory: Aiken, SC, 2008.

7. Bannochie, C. J.; Click, D. R. Tank 40 Final SB5 Chemical Characterization Results Prior to Np Addition; SRNL-STI-2009-00060; Savannah River National Laboratory: Aiken, SC, 2009.

8. Process Science and Engineering Section Procedure Manual; Manual L29; Savannah River National Lab: Aiken, SC, 2007.

9. Stone, M. E. Lab-Scale CPC Equipment Set-up; SRNL-PSE-2006-00074; Savannah River National Laboratory: Aiken, SC, 2006.

10. Pickenheim, B. R. SRAT Assembly for SB5 Shielded Cells Testing: SC-7; SRNL-L31002008-00042; Savannah River National Laboratory: Aiken, SC, 2008.

11. Sludge Batch 5 IV; SRNS-NB-2008-00004; Savannah River National Laboratory: Aiken, SC, 2008.

12. Sludge Batch 5 V; SRNS-NB-2009-00007; Savannah River National Laboratory: Aiken, SC, 2009.

13. Lambert, D. P. Acid Calculation Spreadsheet for DWPF Simulations, Revision 1; InterOffice Memorandum SRNL-PSE-2006-00173; Savannah River National Laboratory: Aiken, SC, 2006. 
14. Jantzen, C. M.; Zamecnik, J. R.; Koopman, D. C.; Herman, C. C.; Pickett, J. B. Electron Equivalents Model for Controlling Reduction-Oxidation (REDOX) Equilibrium during High Level Waste (HLW) Vitrification; WSRC-TR-2003-00126; Savannah River National Laboratory: Aiken, SC, 2003.

15. Jantzen, C. M.; Newell, J. D. Defense Waste Processing Facility (DWPF) Sludge Batch 5 (SB5) Redox Validation; SRNL-PSE-2008-00184; Savannah River National Laboratory: Aiken, SC, 2008.

16. Darby, R., Chemical Engineering Fluid Mechanics, 2nd edition. Marcel Dekker: 2001.

17. Technical Data Summary For the Defense Waste Processing Facility, Part 10; DPSTD-8038-2; Savannah River Site: Aiken, SC, 1982. 


\subsection{ACKNOWLEDGEMENTS}

The authors would like to recognize the invaluable support of the SRNL Shielded Cells technicians and management for the in-cells work; the ACTL technicians for assistance in equipment setup, reagent preparation, and consultation during the SRAT and SME cycles; SRNL-AD researchers and technicians for chemical analyses; and the SRNL Glass Shop for providing glassware and other miscellaneous hardware. 


\section{APPENDIX A. EXCERPT FROM TANK FARM PLANNING SPREADSHEET SB456_010809B.XLS}

\begin{tabular}{|c|c|c|c|c|c|c|c|c|c|}
\hline Date & & & & $5 / 11 / 2009$ & & & & & $05 / 11 / 09$ \\
\hline Tank 51 and 40 & $\begin{array}{c}\text { Steam Outage } \\
4 / 25-5 / 10 / 08\end{array}$ & $\begin{array}{c}\text { Tank } 40 \\
\text { Settled }\end{array}$ & $\begin{array}{c}\text { Decant from } \\
\text { Tank } 40 \\
\end{array}$ & $\begin{array}{c}\text { Tank } 40 \\
\text { after } \\
\text { Decant }\end{array}$ & $\begin{array}{l}40 w t \% \\
\text { NaNO2 }\end{array}$ & $\begin{array}{c}\text { Extra Water } \\
\text { with NaNO2 } \\
\text { for wt } \% \\
\text { NaNO2 of: }\end{array}$ & $\begin{array}{l}\text { Tank } 40 \\
\text { (SB5) } \\
\text { before Np } \\
\text { Add }\end{array}$ & $\begin{array}{l}\text { Np Waste } \\
\text { stream }\end{array}$ & $\begin{array}{c}\text { Tank } 40 \\
\text { after Np } \\
\text { Add }\end{array}$ \\
\hline Initial tank Level (in) & & 142.66 & & 114.10 & & 35.00 & 117.5 & & 120.6 \\
\hline liquid volume (gal) & & 485882 & 100246 & 385636 & 10043.4 & 1893.9 & 397573 & 11000 & 408573 \\
\hline sludge volume (gal) & & 14855 & 0 & 14855 & & & 14855 & 0 & 14855 \\
\hline settled sludge level (in) & & 88.10 & & & & & & & \\
\hline $\mathrm{kg}$ insol. solids & & 184230 & & 184230 & & & 184230 & 0 & 184230 \\
\hline wt $\%$ insol solids & & 8.88 & & 10.94 & & & 10.58 & & 10.27 \\
\hline decant level & & 112.10 & & & & & & & \\
\hline $\mathrm{NO} 2 / \mathrm{NO}$, or kg TS/day from $40 \mathrm{H}$ & & & & & & & 5.55 & & 1.950 \\
\hline \multicolumn{10}{|l|}{ additional nitrite solution } \\
\hline \multicolumn{10}{|l|}{ additional volume } \\
\hline SpG & & 1.027 & 1.027 & 1.0275 & 1.32 & 1 & 1.0347 & 1.25 & 1.0405 \\
\hline $\mathrm{Na}$ & & 0.618 & 0.618 & 0.618 & 7.65 & 0 & 0.7929 & 5.082 & 0.9084 \\
\hline NO2 & & 0.167 & 0.167 & 0.167 & 7.65 & 0 & 0.3553 & 0.0000 & 0.3457 \\
\hline NO3 & & 0.066 & 0.066 & 0.066 & 0 & 0 & 0.0641 & 4.270 & 0.1773 \\
\hline $\mathrm{OH}$ & & 0.269 & 0.269 & 0.269 & 0 & 0 & 0.2606 & 0.6 & 0.2698 \\
\hline $\mathrm{Cl}$ & & 0.002 & 0.002 & 0.002 & 0 & 0 & 0.0020 & 0.0035 & 0.0021 \\
\hline $\mathrm{SO} 4$ & & 0.005 & 0.005 & 0.005 & 0 & 0 & 0.0051 & 0.1015 & 0.0077 \\
\hline $\mathrm{F}$ & & 0.001 & 0.001 & 0.001 & 0 & 0 & 0.0013 & 0.0035 & 0.0013 \\
\hline $\mathrm{CO} 3$ & & 0.042 & 0.042 & 0.042 & 0 & 0 & 0.0412 & 0.0007 & 0.0401 \\
\hline $\mathrm{AlO} 2$ & & 0.031 & 0.031 & 0.031 & 0 & 0 & 0.0300 & 0.0007 & 0.0293 \\
\hline $\mathrm{C} 2 \mathrm{O} 4-2$ & & 0.002 & 0.002 & 0.002 & 0 & 0 & 0.0015 & 0 & 0.0014 \\
\hline PO4-3 & & 0.000 & 0.000 & 0.000 & 0 & 0 & 0.0003 & 0 & 0.0003 \\
\hline K & & 0.001 & 0.001 & 0.001 & 0 & 0 & 0.0012 & 0 & 0.0011 \\
\hline Soluble $\mathrm{Na} 2 \mathrm{C} 2 \mathrm{O} 4, \mathrm{M}$ & & & & 1.111 & & slurry spg= & 1.115 & & 1.119 \\
\hline \multicolumn{10}{|l|}{ Insol Na2C204, kg } \\
\hline NOeff (M) & & & & 0.1442 & & & 0.2332 & & 0.3382 \\
\hline Mass TS, $\mathrm{kg}$ & & 259734 & 15578 & 244156 & 20072 & 0 & 264228 & 16731 & 280959 \\
\hline wt $\%$ TS & & 12.525 & & 14.50 & & & 15.17 & & 15.67 \\
\hline
\end{tabular}


SRNS-STI-2009-00233, REVISION 0

\section{APPENDIX B. DECANT AND ADDITION CALCULATIONS}

\section{DECANT AMOUNT}

\begin{tabular}{|c|c|c|c|c|c|c|c|}
\hline \multicolumn{4}{|c|}{ Inputs } & \multicolumn{4}{|c|}{ Outputs } \\
\hline & A & B & $\mathrm{C}$ & & A & $\mathrm{B}$ & $\mathrm{C}$ \\
\hline 1 & From SB456_010809B S & & & 1 & \multicolumn{3}{|c|}{ From SB456_010809B Spreadsheet } \\
\hline$\frac{2}{3}$ & TKk 40 prior to decant & 142.66 & in & 2 & & & \\
\hline$\frac{0}{4}$ & Tk40 vol & $=\mathrm{B} 3{ }^{*} 3510$ & gal & 3 & Tk 40 prior to decant & 142.66 & in \\
\hline 5 & Tk 40 decant & 100246 & gal decant & 4 & Tk40 vol & 500,737 & gal \\
\hline 6 & & & & 5 & Tk 40 decant & 100,246 & gal decant \\
\hline 7 & SRNL Slurry mass & 2108.72 & g & 6 & & & \\
\hline$\frac{8}{9}$ & Slurry density & 1.09 & $\mathrm{~g} / \mathrm{mL}$ & 7 & SRNL Slurry mass & 2,109 & g \\
\hline$\frac{9}{10}$ & sup density & 1.04 & $\mathrm{~g} / \mathrm{mL}$ & 8 & Slurry density & 1.09 & $\mathrm{~g} / \mathrm{mL}$ \\
\hline 10 & $\begin{array}{l}\text { Slurry vol } \\
\text { wt\% IS }\end{array}$ & $\begin{array}{l}=\mathrm{B} 7 / \mathrm{B} 8 \\
0.095\end{array}$ & $\mathrm{~mL}$ & 9 & sup density & 1.04 & $\mathrm{~g} / \mathrm{mL}$ \\
\hline \begin{tabular}{|l|}
12 \\
\end{tabular} & $\mathrm{Wt} \% \mathrm{TS}$ & 0.134 & & 10 & slurry vol & 1,935 & $\mathrm{~mL}$ \\
\hline 13 & $\mathrm{wt} \% \mathrm{DS}$ & 0.0429 & & 11 & wt\% IS & $9.50 \%$ & \\
\hline 14 & & & & 12 & Wt\% TS & $13.40 \%$ & \\
\hline 15 & Decant volume & $=\mathrm{B} 10 * \mathrm{~B} 5 / \mathrm{B} 4$ & $\mathrm{~mL}$ & 13 & $w t \% D S$ & $4.29 \%$ & \\
\hline 16 & Decant Mass & $=\mathrm{B} 15^{*} \mathrm{~B} 9$ & g & 14 & & & \\
\hline 17 & solids removed in decant & $=\mathrm{B} 16^{*} \mathrm{~B} 13$ & g & 15 & Decant volume & 387 & $\mathrm{~mL}$ \\
\hline & & & & 16 & Decant Mass & 403 & $g$ \\
\hline 18 & Post Decant Slurry mass & $=\mathrm{B} 7-\mathrm{B} 16$ & g & & solids removed in & & \\
\hline 19 & Post decant solids mass & $=\mathrm{B} 7{ }^{*} \mathrm{~B} 12-\mathrm{B} 17$ & $g$ & 17 & decant & 17.3 & $g$ \\
\hline \begin{tabular}{|l|}
20 \\
\end{tabular} & new wt $\%$ TS & $=\mathrm{B} 19 / \mathrm{B} 18$ & (calculated) & & Post Decant Slurry & & \\
\hline \begin{tabular}{|l|}
21 \\
\end{tabular} & new wt $\%$ IS & $=\mathrm{B} 11^{*} \mathrm{~B} 7 / \mathrm{B} 18$ & (calculated) & 18 & mass & 1,706 & $g$ \\
\hline & & & & 19 & $\begin{array}{l}\text { Post decant solids } \\
\text { mass }\end{array}$ & 265 & g \\
\hline & & & & 20 & new wt\% TS & $15.6 \%$ & (calculated) \\
\hline & & & & 21 & new wt $\%$ IS & $11.7 \%$ & (calculated) \\
\hline
\end{tabular}




\section{ADDITIONS}

\begin{tabular}{|c|c|c|c|c|c|c|}
\hline & SRNL & & Tank Farm & & & \\
\hline Slurry Mass & $=$ 'Decant calc'!D24 & $\mathrm{g}$ & & & & \\
\hline Slurry Density & $=$ 'Decant calc'!B25 & $\mathrm{g} / \mathrm{mL}$ & & & & \\
\hline Slurry $\mathrm{Ht}$ & & & 114 & in & & \\
\hline Slurry Volume & $=\mathrm{B} 4 / \mathrm{B} 5$ & $\mathrm{~mL}$ & $=\mathrm{D} 6 * 3510$ & gal & & \\
\hline wt $\%$ IS & $=$ 'Decant calc'!H22 & & 0.109 & & & \\
\hline Mass IS & $=\mathrm{B} 4{ }^{*} \mathrm{~B} 8$ & $g$ & & & & \\
\hline Wt\% TS & ='Decant calc'!H21 & & 0.152 & & & \\
\hline Mass TS & $=\mathrm{B} 10^{*} \mathrm{~B} 4$ & g & & & & \\
\hline NaNO2 (40wt\% solution) & $=\mathrm{D} 13 / \mathrm{D} 7{ }^{*} \mathrm{~B} 7$ & $\mathrm{~mL}$ & 10043 & gal & & \\
\hline Water & $=\mathrm{D} 14 / \mathrm{D} 7{ }^{*} \mathrm{~B} 7$ & $\mathrm{~mL}$ & 1894 & gal & & \\
\hline Total H Canyon discharge & $=\mathrm{D} 16 / \mathrm{D} 7{ }^{*} \mathrm{~B} 7$ & $\mathrm{~mL}$ & 11000 & gal & & \\
\hline NO3 & 4.27 & M & & & & \\
\hline $\mathrm{OH}$ & 0.6 & M & & & & \\
\hline Total NO3 & $=\mathrm{B} 16^{*} \mathrm{~B} 17$ & $\mathrm{mmol}$ & & & & \\
\hline Total $\mathrm{OH}$ & $=\mathrm{B} 18^{*} \mathrm{~B} 16$ & $\mathrm{mmol}$ & & & & \\
\hline Np Mass & $=\mathrm{D} 21^{*} 1000 /(\mathrm{D} 7 * 3785)^{*} \mathrm{~B} 7$ & $\mathrm{~g}$ & 21 & $\mathrm{~kg}$ & & \\
\hline In(fr 9.6 smple Np Vol & $=\mathrm{B} 21 / 0.0014$ & $\mathrm{~mL}$ & & & & \\
\hline $\mathrm{NO3}$ & 7.35 & $\mathrm{M}$ & & & & \\
\hline $\mathrm{NO3}$ & $=\mathrm{B} 23^{*} \mathrm{~B} 24$ & $\mathrm{mmol}$ & & & & \\
\hline Needed Additions & & & & & & \\
\hline $\mathrm{NO3}$ & $=\mathrm{B} 19-\mathrm{B} 25$ & $\mathrm{mmol}$ & & & & \\
\hline $\mathrm{OH}$ & $=\mathrm{B} 20+(\mathrm{B} 25+\mathrm{B} 28)$ & $\mathrm{mmol}$ & & & & \\
\hline & & & density & & mass & \\
\hline $19 \mathrm{M} \mathrm{NaOH}$ & $=\mathrm{B} 29 / 19$ & $\mathrm{~mL}$ & 1.52 & $\mathrm{~g} / \mathrm{mL}$ & $=\mathrm{B} 31^{*} \mathrm{D} 31$ & $\mathrm{~g}$ \\
\hline Con Nitric acid & $=\mathrm{B} 28 / 15.9$ & $\mathrm{~mL}$ & 1.42 & $\mathrm{~g} / \mathrm{mL}$ & $=\mathrm{B} 32 * \mathrm{D} 32$ & g \\
\hline Water & $=\mathrm{B} 16-\mathrm{B} 23-\mathrm{B} 31-\mathrm{B} 32$ & $\mathrm{~mL}$ & 1 & $\mathrm{~g} / \mathrm{mL}$ & $=B 33^{*} \mathrm{D} 33$ & $\mathrm{~g}$ \\
\hline
\end{tabular}


SRNS-STI-2009-00233, REVISION 0

\section{Output}

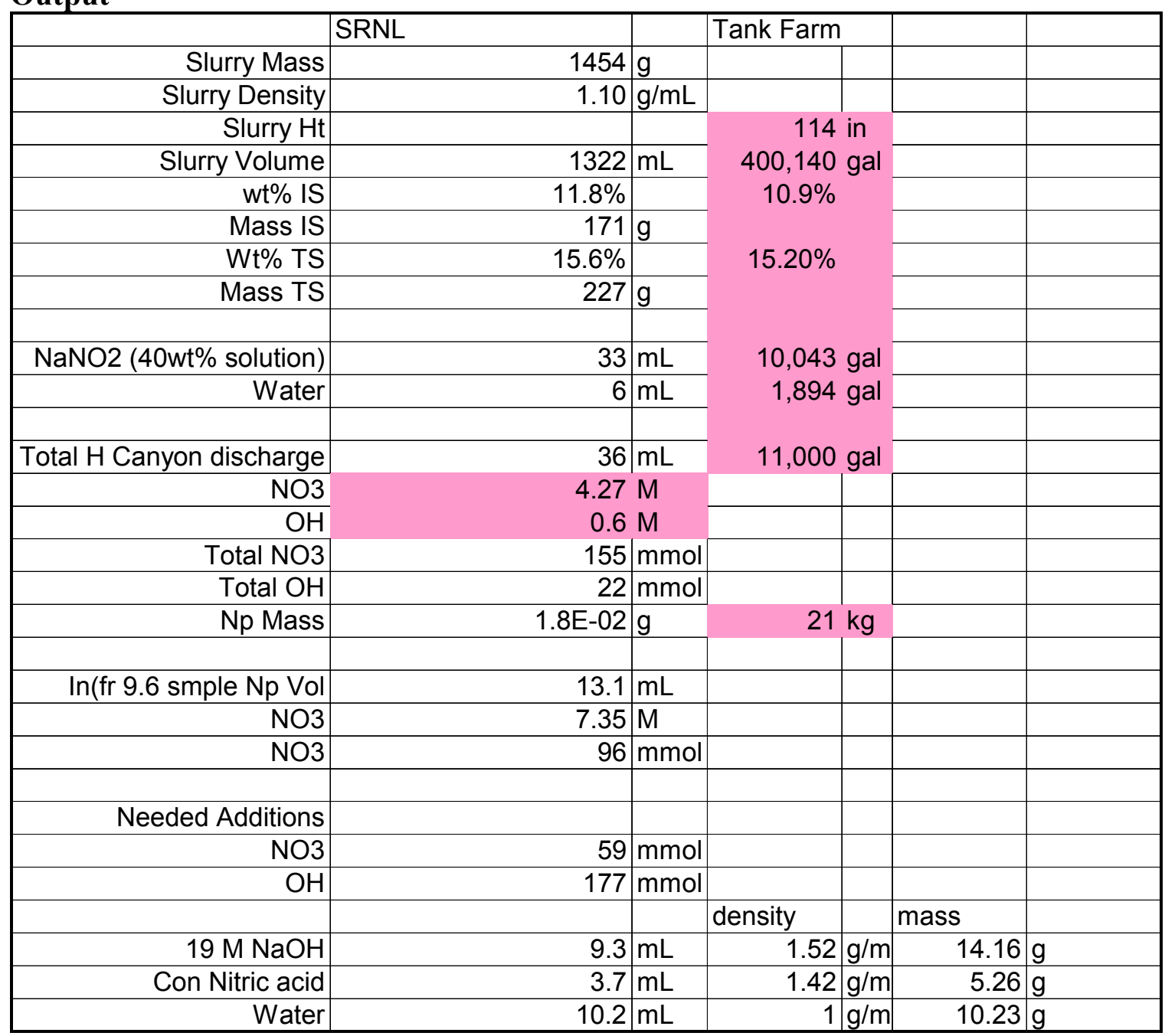


SRNS-STI-2009-00233, REVISION 0

\section{APPENDIX C. RESULTS OF SRAT CYCLE PERIODIC SAMPLES}

\begin{tabular}{|c|c|c|c|c|c|}
\hline & Time at & $\mathrm{Hg} w \mathrm{wt}$ & & & \\
\hline AD LIMS & boiling $(\mathrm{h})$ & of TS & Average & stdev & $\%$ RSD \\
\hline 300256865 & 12 & $0.92 \%$ & $0.96 \%$ & $0.06 \%$ & $6.24 \%$ \\
\hline 300256866 & 12 & $1.01 \%$ & & & \\
\hline 300256867 & 20 & $0.49 \%$ & $0.60 \%$ & $0.16 \%$ & $26.34 \%$ \\
\hline 300256868 & 20 & $0.71 \%$ & & & \\
\hline 300256869 & 28 & $0.21 \%$ & $0.21 \%$ & $0.01 \%$ & $6.22 \%$ \\
\hline 300256870 & 28 & $0.22 \%$ & & & \\
\hline 300256871 & 36 & $0.12 \%$ & $0.12 \%$ & $0.00 \%$ & $1.84 \%$ \\
\hline 300256872 & 36 & $0.12 \%$ & & & \\
\hline 300256873 & 44 & $0.09 \%$ & $0.10 \%$ & $0.01 \%$ & $5.41 \%$ \\
\hline 300256874 & 44 & $0.10 \%$ & & & \\
\hline
\end{tabular}

\begin{tabular}{|l|c|c|c|}
\hline & & Formate & Nitrate \\
\hline & & mg/kg slurry & mg/kg slurry \\
\hline 12 Hr Boil & Sample A & 46034 & 31558 \\
\hline & Sample B & 43199 & 30064 \\
\hline & Average & $\mathbf{4 . 4 6 E + 0 4}$ & $\mathbf{3 . 0 8 E + 0 4}$ \\
\hline & Std Dev & 2004 & 1056 \\
\hline & \%RSD & 4.5 & 3.4 \\
\hline & Sample A & 45479 & 31590 \\
\hline & Sample B & 40397 & 30795 \\
\hline & Average & $\mathbf{4 . 2 9 E + 0 4}$ & $\mathbf{3 . 1 2 E + 0 4}$ \\
\hline & Std Dev & 3593 & 563 \\
\hline & \%RSD & 8.4 & 1.8 \\
\hline & Sample A & 38006 & 29283 \\
\hline & Sample B & 41896 & 32315 \\
\hline & Average & $\mathbf{4 . 0 0 E + 0 4}$ & $\mathbf{3 . 0 8 E + 0 4}$ \\
\hline & Std Dev & 2750 & 2143 \\
\hline & \%RSD & 6.9 & 7.0 \\
\hline $36 \mathrm{Hr}$ Boil & Sample A & 37669 & 31487 \\
\hline & Sample B & 40549 & 31928 \\
\hline & Average & $\mathbf{3 . 9 1 E + 0 4 4}$ & $\mathbf{3 . 1 7 E + 0 4}$ \\
\hline & Std Dev & 2037 & 312 \\
\hline & \%RSD & 5.2 & 1.0 \\
\hline
\end{tabular}




\section{Distribution:}

S. L. Marra, 773-A

A. B. Barnes, 999-W

D. A. Crowley, 773-43A

S. D. Fink, 773-A

C. W. Gardner, 773-A

B. J. Giddings, 786-5A

C. C. Herman, 999-W

F. M. Pennebaker, 773-42A

A. M. Murray, 773-A

J. E. Occhipinti, 704-S

D. C. Sherburne, 704-S

R. T. McNew, 704-27S

J. F. Iaukea, 704-30S

J. W. Ray, 704-S

H. B. Shah, 766-H

J. M. Gillam, 766-H

B. A. Hamm, 766-H

D. D. Larsen, 766-H

C. J. Bannochie, 773-42A

D. J. McCabe, 773-42A

D. K. Peeler, 999-W

N. E. Bibler, 773-A

A. I. Fernandez, 999-W

D. C. Koopman, 999-W

D. P. Lambert, 999-W

B. R. Pickenheim, 999-W

S. H. Reboul, 773-42a

M. E. Stone, 999-W

J. M. Bricker, 704-27S

T. L. Fellinger, 704-26S

E. W. Holtzscheiter, 704-15S

J. P. Vaughan, 773-41A

M. A. Broome, 704-29S

A. J. Cross, 704-71S

H. J. Kunis, 704-S 